\title{
MYANMAR: LONG-TERM SCENARIOS FOR SUSTAINED MACROECONOMIC GROWTH
}

David Roland-Holst and Cyn-Young Park

NO. 429

April 2015
ADB ECONOMICS WORKING PAPER SERIES 
ADB Economics Working Paper Series

\section{Myanmar: Long-Term Scenarios for Sustained Macroeconomic Growth}

David Roland-Holst and Cyn-Young Park

No. 429 | April 2015
David Roland-Holst (dwrh@berkeley.edu) is a professor at the University of California Berkeley. Cyn-Young Park (cypark@adb.org) is Director for Economic Analysis and Operational Support Division in the Economic Research and Regional Cooperation Department of the Asian Development Bank.

The authors also thank Adam Solimon, John Wisniowski, and Paulo Rodelio M. Halili for excellent research assistance and colleagues at the Asian Development

Bank for a productive discussion. 
Asian Development Bank

6 ADB Avenue, Mandaluyong City

1550 Metro Manila, Philippines

www.adb.org

(C) 2015 by Asian Development Bank

April 2015

ISSN 2313-6537 (Print), 2313-6545 (e-ISSN)

Publication Stock No. WPS157223-2

The views expressed in this paper are those of the authors and do not necessarily reflect the views and policies of the Asian Development Bank (ADB) or its Board of Governors or the governments they represent.

ADB does not guarantee the accuracy of the data included in this publication and accepts no responsibility for any consequence of their use.

By making any designation of or reference to a particular territory or geographic area, or by using the term "country" in this document, $A D B$ does not intend to make any judgments as to the legal or other status of any territory or area.

Note: In this publication, "\$” refers to US dollars.

The ADB Economics Working Paper Series is a forum for stimulating discussion and eliciting feedback on ongoing and recently completed research and policy studies undertaken by the Asian Development Bank (ADB) staff, consultants, or resource persons. The series deals with key economic and development problems, particularly those facing the Asia and Pacific region; as well as conceptual, analytical, or methodological issues relating to project/program economic analysis, and statistical data and measurement. The series aims to enhance the knowledge on Asia's development and policy challenges; strengthen analytical rigor and quality of ADB's country partnership strategies, and its subregional and country operations; and improve the quality and availability of statistical data and development indicators for monitoring development effectiveness.

The ADB Economics Working Paper Series is a quick-disseminating, informal publication whose titles could subsequently be revised for publication as articles in professional journals or chapters in books. The series is maintained by the Economic Research and Regional Cooperation Department. 


\section{CONTENTS}

TABLES AND FIGURES $\quad$ iv

ABSTRACT $v v v$

$\begin{array}{ll}\text { I. INTRODUCTION } & 1\end{array}$

II. SCENARIOS FOR LONG-TERM GROWTH

A. An Economic Forecasting Model for Myanmar 1

B. Core Growth 3

C. Support for Growth 8

III. RESULTS AND INTERPRETATION

A. Macroeconomic Results $\quad 12$

B. Structural Results $\quad 17$

C. Labor Markets, Employment, and Migration 18

D. Demographic Transition 19

$\begin{array}{ll}\text { IV. CONCLUSIONS } & 20\end{array}$

APPENDIX 1: MODEL SUMMARY 23

APPENDIX 2: OVERVIEW OF MYANMAR DATA RESOURCES 32

$\begin{array}{ll}\text { BIBLIOGRAPHY } & 39\end{array}$ 


\section{TABLES AND FIGURES}

\section{TABLES}

$1 \quad$ Average Annual Growth of Agricultural Output 4

2 Scenario Summary 11

3 Macroeconomic Aggregates $\quad 13$

4 Sectoral Employment Impacts $\quad 19$

\section{FIGURES}

$1 \quad$ Rice Yields by Country/Region, 1960-2010 4

$2 \quad$ Factor Productivity Growth in Asia, 1999-2008 6

3 Real Gross Domestic Product Growth by Scenario 12

$4 \quad$ Overall and Incremental Gross Domestic Product Growth by Scenario 14

5 Sectoral Growth Dynamics Under Two Scenarios 18

6 Population Composition and Dependency Ratio 20 


\begin{abstract}
We use a dynamic forecasting model to evaluate a wide array of opportunities for sustained economic growth in Myanmar. Our simulation results suggest that the government of Myanmar can advance potential growth drivers, by maintaining a stable macroeconomic environment that is conducive to private investment, promoting human capital development and public investment, facilitating domestic and international private agencies for market development, and strengthening regional economic integration. The government needs a balanced approach to sector interests to promote inclusive and equitable growth. Increasing agricultural productivity, for example, will not only benefit the country's rural poor majority, but it will also release labor resources to facilitate industrial and service sector development. Conversely, industrial and urban development will facilitate agrifood supply chains, improving market access and real incomes in rural areas. Public commitments to improving infrastructure, education, and public health will also be essential to realizing Myanmar's vast economic potential.
\end{abstract}

Keywords: Calibrated General Equilibrium (CGE) model, economic forecasting, Myanmar, policy simulation, potential growth

JEL Classification: D58, F41, O11, O47 


\section{INTRODUCTION}

Myanmar stands at the early stages of a pervasive institutional reform and development process for economic development and it would be easy to become preoccupied with challenges. This report takes a different perspective, examining a wide array of opportunities Myanmar has to achieve the sustained economic growth already enjoyed by many of its Asian neighbors. Using a state-of-the-art policy decision tool, a new long-term economic forecasting model, we investigate the many drivers of growth that exist for this resource-rich and diverse economy, embedded in one of the most dynamic economic regions of the world. Our results are intended to contribute to a new generation of evidence-based growth policy that will support Myanmar's successful economic transition.

Our results reveal how determined commitments to productivity enhancement, accelerated public and private investment, and open multilateralism offer the country unprecedented leverage for sustained macroeconomic growth and smoother transition to a more prosperous, inclusive economic future. In particular, policies that promote agrifood productivity, diversification, and higher valueadded can buttress equitable growth and food security. More targeted sectoral strategies in resource intensive, industrial, and service sectors will also unlock superior growth potential. More fundamentally, comprehensive expansion of education and training systems will be needed to capture the benefits of international competitiveness for the majority of its population. All these measures must also be complemented by the infrastructure investments needed to improve market access, promoting enterprise development and poverty reduction nationally. Finally, Myanmar's growth can be sharply accelerated by leveraging external savings, in the form of foreign direct investment, to overcome domestic investment constraints while promoting technology transfer and export market access. All these strategies have of course been deployed in the region by the most successful Asian economies, so there is ample precedent to guide policy by example.

Using modern research techniques to support more effective policy is also a hallmark of successful growth experiences, in Asia and globally, and it is hoped that the present exercise will provide new impetus for rigorous ex ante policy assessment and targeting for growth, equity, and sustainability. Much work remains to be done in this area, particularly to improve original information and analytical support available to decision makers. In light of these constraints, the present contribution must be seen as preliminary, but continuing in the direction of this capacity development can substantially improve the coherence and effectiveness of public policy dialogue, as well as the decisions of private stakeholders who must anticipate public policy and make essential contributions to inclusive economic development.

\section{SCENARIOS FOR LONG-TERM GROWTH}

\section{A. An Economic Forecasting Model for Myanmar}

In this section, we apply a new dynamic economic forecasting model to evaluate long-term growth prospects for Myanmar. The framework we developed is an advanced policy simulation tool that models demand, supply, and resource allocation across the Myanmar economy, estimating economic outcomes annually over the period 2014-2030. This kind of model (called a Calibrated General Equilibrium or (GE) is a state-of-the-art forecasting tool, using a system of equations and detailed economic data that simulate price-directed interactions between firms and households in commodity and factor markets. The role of government, capital markets, and other trading partners are also 
included, with varying degrees of detail, to close the model and account for economy-wide resource allocation, production, and income determination.

The role of markets is to mediate exchange, usually with flexible market prices, the most important variables in a typical CGE model. As in a real market economy, commodity and factor price changes induce changes in the level and composition of supply and demand, production and income, and the remaining endogenous variables in the system. In CGE models, the model equations are solved for prices that correspond to market equilibrium of supply and demand. If such a system is precisely specified, equilibrium always exists and a consistent model can be calibrated to base period data. The resulting CGE model is then used to simulate the economy-wide impacts under different policy and external event scenarios.

The distinguishing feature of a general equilibrium model, applied or theoretical, is its closed-form specification of all specified activities in the economic system under study. This can be contrasted with more traditional partial equilibrium analysis, where linkages to other domestic markets and agents are deliberately excluded from consideration. A large and growing body of evidence suggests that indirect effects (e.g., upstream and downstream production linkages) arising from policy changes are not only substantial, but may in some cases even outweigh direct effects. Only a model that consistently specifies economy-wide interactions can fully assess the implications of economic policies or business strategies. In a multi-country model like the one used in this study, indirect effects include the trade linkages between countries and regions, which themselves can have policy implications.

The model we use for this work has been constructed according to generally accepted specification standards, implemented in the General Algebraic Modeling System (GAMS) programming language, and calibrated to the new Myanmar Social Accounting Matrix (SAM) estimated for the year 2012.' The result is a single economy model calibrated over the 20-year time path from 2010 to $2030 .^{2}$

\section{Why Use an Economic Model?}

Myanmar's reform policies are shaped by public aspirations for better livelihoods, and also by a collective sense that economic modernization and market-oriented institutions can deliver sustained economic growth. These "animal spirits" are essential to large-scale economic mobilization and the intuition behind them is of course consistent with the dynamic Asian growth experience. Having said this, however, today's global economy is so complex that policymakers relying on intuition alone are unlikely to achieve anything close to optimality. For this reason, evidence-based policy generally, and economic forecasting, in particular, have become essential tools for decision makers. This kind of scenario analysis enables policymakers to assess the effects of alternative development strategies before they are implemented, avoiding unanticipated costs and irreversibilities.

\section{Why a Regional Model?}

Because of unique geographic and institutional characteristics, Myanmar needs its own research capacity to support its own policies. The role of trade as a catalyst for growth makes regional and

See, e.g., Brooke, Kendrick, and Meeraus (1992) for GAMS.

2 The present specification is one of the most advanced examples of this empirical method, already applied to over 50 individual countries and/or regions. Complete technical documentation of the Myanmar CGE model and 2012 SAM are available from the authors upon request. 
international assessments essential. Public and private stakeholders need more accurate prior information about the adjustment process to participate effectively. Projects may be local or national, but spillover effects implicate stakeholders across borders. This can arouse both cooperative and competitive interests, both of which need to be anticipated.

\section{Why a General Equilibrium Model?}

General Equilibrium (GE) models capture extensive interactions, thought markets, production systems, and expenditure decisions. These forecasting tools reveal more detailed economic impacts and support more effective policy from three perspectives:

i. Complexity. Given the complexity of today's market economies, policy makers relying on intuition and rules-of-thumb alone are assuming substantial risks.

ii. Linkage. Indirect effects of policies often outweigh direct effects.

iii. Political sustainability. Economic policy may be made from the top down, but political consequences are often felt from the bottom up.

GE models, supported by reliable data resources, can elucidate these linkages and improve visibility for policy makers. Moreover, this kind of simulation framework permits them to identify benefits and costs ex ante, recruiting those who gain to support policies and anticipating the adjustment needs of others.

\section{Data Sources}

The data for the Myanmar CGE were obtained from a variety of official national, multilateral, and academic sources. Most of the economic data are compiled in a new (2012) Social Accounting Matrix for Myanmar, estimated by the authors for this research activity. The detail, timeliness, and accuracy of Myanmar economic and demographic data remain a significant challenge for effective policy support, but progress is being made rapidly in this area. Data resources for the current research are discussed in more detail in Appendix 2. Our results are of course subject to constraints regarding data quality, but we believe it is more important to deliver indicative findings than to ignore available evidence. Generally speaking, sensitivity analysis indicates that the main findings of this analysis are robust.

\section{B. Core Growth}

We applied the Myanmar CGE model to evaluate a series of forecasting scenarios. These empirical exercises, and the results they provide, are intended to elucidate opportunities and challenges that the country faces in its transition to a more diverse market economy that delivers higher living standards to its population. While the actual growth process will depend on many other factors, these scenarios isolate some of the main growth drivers and impacts that can be expected from public and private actions that promote/facilitate them. These core growth drivers, including agriculture, industry, and service sector development, will be evaluated with the scenarios described below.

\section{Agriculture}

Among Southeast Asian nations, the Union of Myanmar has the largest share of agriculture in gross domestic product (GDP), about 40\% according to independent estimates, as well as the highest population proportion of low-income smallholders. Although Myanmar is officially classified as a food surplus economy, $16 \%$ of the country's 50.5 million population, or a total of 7.8 million individuals, 
suffer from undernourishment (last recorded in 2007, but down from 13.5 million in 2001). Moreover, subsistence production remains the dominant pattern of agriculture in the country. All these attributes making Myanmar a leading candidate for agriculture and food-oriented development strategies.

\section{Table 1: Average Annual Growth of Agricultural Output}

\begin{tabular}{lcccc}
\hline & $1970-1979$ & $1980-1989$ & $1990-1999$ & $2000-2006$ \\
Sub-Saharan Africa & 1.31 & 2.6 & 3.1 & 2.2 \\
Latin America and Caribbean & 3.07 & 2.37 & 2.87 & 3.13 \\
Brazil & 3.83 & 3.73 & 3.29 & 4.41 \\
Middle East and North Africa & 2.94 & 3.37 & 2.73 & 2.34 \\
NE Asia, High & 2.15 & 1.03 & -0.01 & -0.01 \\
NE Asia, Low & 3.11 & 4.55 & 5.06 & 3.85 \\
PRC & 3.09 & 4.6 & 5.17 & 3.87 \\
SE Asia & 3.68 & 3.59 & 3.13 & 3.54 \\
South Asia & 2.56 & 3.39 & 3 & 2.19 \\
India & 2.69 & 3.52 & 2.94 & 2 \\
North America & 2.17 & 0.73 & 2.03 & 1.1 \\
Oceania & 1.79 & 1.25 & 2.93 & -0.04 \\
Western Europe & 1.54 & 0.94 & 0.46 & -0.35 \\
Eastern Europe & 1.8 & 0.25 & -2.18 & -0.19 \\
Russian Federation & 1.32 & 0.98 & -4.62 & 2.7 \\
Developing countries & 2.82 & 3.46 & 3.64 & 3.09 \\
Developed countries & 1.88 & 0.86 & 1.21 & 0.39 \\
Russian Fed. and Eastern Europe & 1.47 & 0.77 & -3.88 & 1.81 \\
World & 2.23 & 2.13 & 2.04 & 2.22 \\
\hline
\end{tabular}

$\mathrm{NE}=$ northeast, $\mathrm{PRC}=$ People's Republic of China, $\mathrm{SE}=$ southeast.

Source: FAO. FAOSTAT database. http://faostat3.fao.org (accessed 5 October 2013).

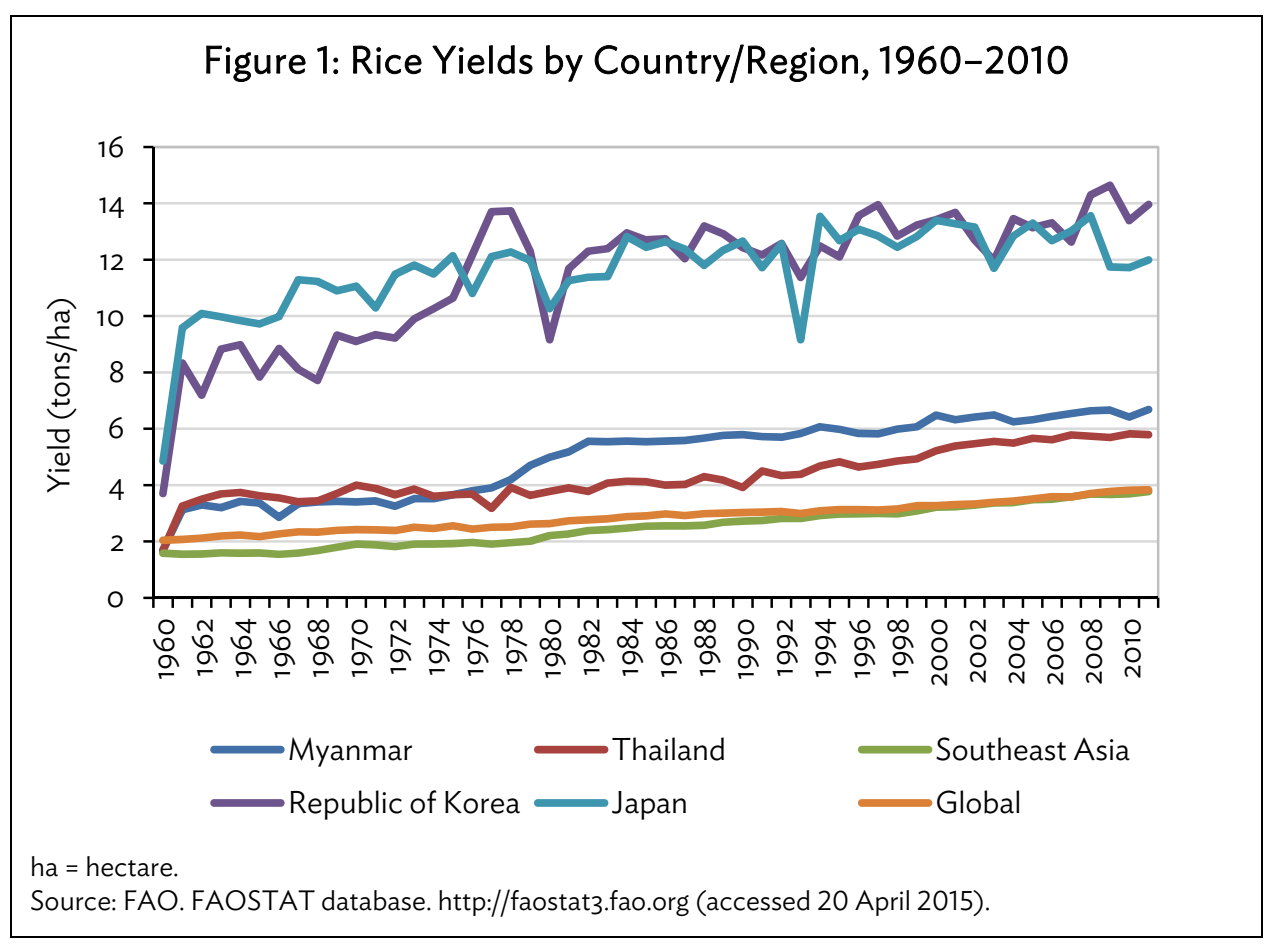




\section{a. Productivity Potential: The Case of Rice}

Because of geographic diversity and differences in stages of development, agricultural yields and productivity vary substantially around the world (Table 1). In Myanmar, it is generally agreed that, agrifood production is far below its ultimate potential, especially when higher value-added products are considered. Because of relatively small-scale land tenure patterns, it is unlikely that rural households in these countries can achieve significant livelihood improvements, unless value per hectare improves substantially.

In an initial set of productivity scenarios, we examine the potential for higher rice output to benefit Myanmar and its majority rural population. As Figure 1 indicates, Myanmar rice yields are high by both regional and global standards, but still well below the potential that can be realized with higher levels of investment and intensification. Of course, it will take significant time and resources before Southeast Asian nations achieve yields established in Japan and the Republic of Korea, but even partial narrowing of this gap would have momentous implications for the poor rural majority in Myanmar.

In particular, we assume for this scenario that Myanmar can improve rice yields by $2 \%$ annually over the next 2 decades, which would overcome half the gap between their productivity and that of the most productive Asian economies. This growth rate is consistent with other Southeast Asian experience, and it must be understood that Myanmar will not be able to afford the rates of technology adoption seen in Korean and Japanese rice production over the last generation.

Rice is both an essential staple and a historic source of global export opportunity, but rice exports may not be the best way to promote inclusive growth with Myanmar's agricultural resources. Meeting domestic food needs from its own rice sector can be important to both the rural and urban poor because it keeps food costs low and stable. Once sufficiency is reached, however, cereals generally, and rice, in particular, offers limited value-added or livelihoods upside to the rural poor. Most evidence from low and middle-income exporters (e.g., Thailand) suggests that increasing grain yields for export is of limited benefit to the poor, and is merely increasing inequality. Processors and traders, rather than smallholders, capture most of the incremental income from external markets.

\section{b. Diversification}

Agrifood diversification for domestic and regional markets may have higher risk-adjusted returns to Myanmar farmers than expanding rice monoculture. Excessive national reliance on a single cash crop entails substantial risks, as we have seen in a long history of commodity price cycles. Moreover, cereals have relatively low income elasticities, meaning that they underperform as export crops in a rapidly prospering regional market like Asia. By contrast, specialty agriculture (e.g., livestock products, fruits, and vegetables) and higher value-added agrifood products are the bases of one of the most dynamic supply chains in the region. Decades of experience with globalization has revealed limited direct benefits for the world's rural poor majority. In some countries, however, domestic agrifood supply chains have allowed the rural poor to participate indirectly in urban growth, marketing more income elastic agrifood products to cities. Thus, agricultural diversification may yield more inclusive growth for Myanmar, if productivity can be promoted across a broader spectrum of farm products. In these scenarios, we examine the growth potential from more general agrifood productivity growth.

\section{c. Agrifood Value-Added}

One of the defining characteristics of low-income economies everywhere is limited reserves of domestic saving, which in turn limits the progress of development by restricting investment in 
productive assets and enterprise expansion. The era of globalization has changed the nature of this constraint, however, with the advent of transboundary or foreign direct investment (FDI) that permits low-income countries to leverage foreign savings for domestic investment, technological change, and growth. To help low-income economies achieve their economic potential in the timeliest fashion, FDI can be an essential catalyst. The same logic applies to rural poor enclaves within middle-income Greater Mekong Subregion (GMS) economies. Savings disparities between urban and rural areas are only partially offset by migrant remittances and public rural development schemes. Improving domestic market access and smallholder productivity could accelerate private investment from urban to rural areas, and from large to small agrifood enterprise development.

\section{Industry - Investment for Growth, Competitiveness, and Value-Added}

Industrial strategy has been the bedrock of successful Asian growth policies, and it will be no less fundamental to Myanmar's efforts to achieve sustained prosperity. In this report, we make no prescriptions about the choice of leading sectors, but only emphasize the importance of a balanced reform process that promotes productivity growth and investment incentives across the economy. As Figure 2 makes clear, economic dynamism across Asia has varied with factor productivity, and countries in this "league table" owe a large part of their growth successes to more efficient technology and workers.

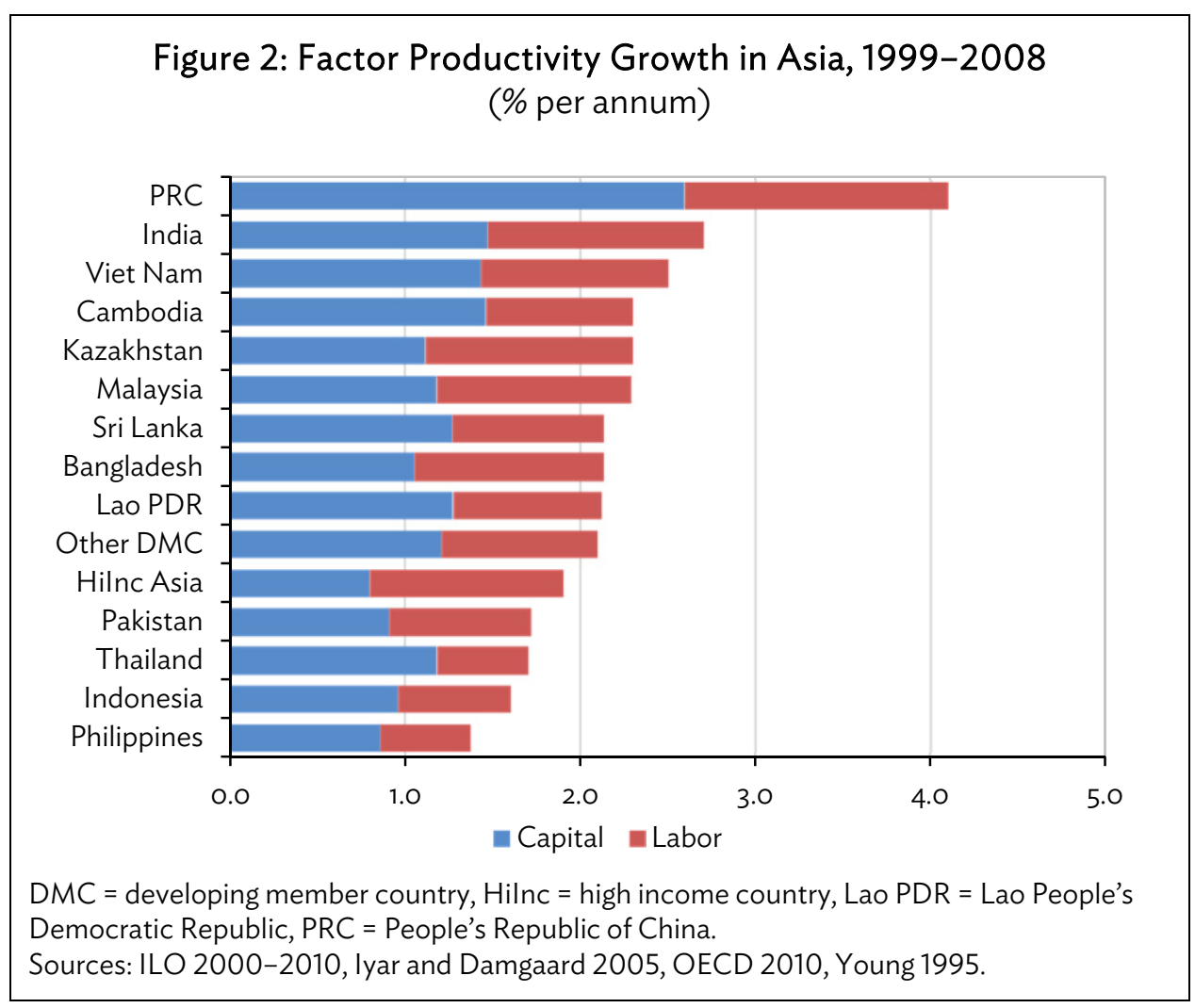

Although the present report focuses on the macroeconomic growth outcomes, it is important for policy makers to be able to assess the potential contributions of individual sectors to aggregate growth dynamics. To elucidate these structural issues, we consider a series of sector-specific scenarios for factor productivity growth, collecting activities into generic product groups. In each case, we 
construct a trend where total factor productivity (TFP) growth of the target sectors rises to meet the GMS average by 2020 and remains there for a decade.

\section{a. $\quad$ Resource-Based Industries}

Myanmar is blessed with rich natural resources and, while exploiting these can entail sustainability challenges, they will continue to be an important source of growth and income to the country. To better understand how resource-intensive industries can contribute to economy-wide growth, we consider the effects of productivity enhancement in six of the model's 23 sectors:

i. Forest products;

ii. Fishery and aquaculture;

iii. Oil, gas, and coal extraction;

iv. Other mineral mining;

v. Paper products and publishing; and

vi. Refined petroleum products.

\section{b. Light Industries}

Across the Asian region, light industry has been an early emerging source of export opportunity and employment. The main reasons are its relatively labor intensive and lower skill requirements, which are complemented in a labor surplus economy by globally competitive wages. Based on initial conditions, Myanmar looks to be a good candidate for this kind of leading sector promotion, but its ultimate success will be an empirical question. To better understand this opportunity, we consider productivity enhancement in four typical light industry sectors:

i. Processed food;

ii. Beverages and tobacco;

iii. Textiles; Apparel and footwear; and

iv. Wood products.

\section{c. Manufacturing}

Myanmar already has some manufacturing activities, and it is natural for an economy of this size to develop more of them. Subject to initial conditions, in terms of investible capital, technology, and skills, a wide array of products could be produced for the domestic and export markets. To assess this opportunity, we examined the implications of TFP growth in the following sectors:

i. Chemical products;

ii. Nonmetal minerals;

iii. Metal products;

iv. Machinery; and

v. Transport equipment, Electronics.

\section{Services: Modernization and Diversification}

With relatively low capital and skill requirements, service sectors are always an attractive growth opportunity for emerging economies. Policies in this area can be challenging because of the 
heterogeneity and generally small-scale of the enterprise sectors involved, but these same characteristics make successful growth more inclusive and equitable. Finally, Myanmar's natural endowments suggest that it could be a very effective competitor in the global tourism sector, one of the few early stage service activities that has significant foreign exchange potential. With these considerations in mind, we included two generic productivity scenarios for these two sectors in the Myanmar CGE model.

\section{Support for Growth}

Private agency can accomplish remarkable things when it comes to the economy, but the best efforts of enterprises and workers can only reach their ultimate potential with determined commitments to deliver public goods and services that markets have historically underprovided. These include, but are not limited to, a wide array of human services infrastructure for transportation, energy access, and communication. The following scenarios are intended to elucidate the macroeconomic significance of these publicly delivered growth drivers.

\section{Human Development}

It is a truism that value depends on quality, and quality depends on performance, but labor markets bring this concept to reality in the economic growth process. The quality of human capital, in terms of productivity, is the most fundamental determinant of real wages, livelihoods, and growth. That same quality, in turn, is determined by more complex factors, including education, its private counterpart training, health status, and the efficiency of labor markets in matching workers with productive and skill-appropriate tasks. In this brief analysis, we consider education and health status as macro drivers of growth via their influence on labor productivity, using the historical experience of Myanmar's GMS neighbors as a reference. This macro approach greatly simplifies the human capital story, but the results are startling and should focus the attention of the policy community on how to expedite progress in this area.

\section{a. Education}

There is a vast literature on education's contribution to growth (see, e.g., Schultz 1960, 1961, and 1971; Self and Grabowski 2004; Bils and Klenow 2000). While the findings are almost uniformly positive, however, magnitudes vary by country, level of average educational attainment, and occupation. After an exhaustive survey of empirical work relevant to Asian dynamic export economies, we specified a scenario for Myanmar that reflects success stories in the same region. Generally speaking, East and Southeast Asian economies transitioning from low to middle or high-income status over a comparable (approximately 20 years) time period, improved education-induced labor productivity at a rate that, for Myanmar, would lead to a 30\% increase across skill levels by 2030 . Of course, this progress is heterogeneous, depending on initial conditions and the composition of public and private investments in education and training. Elucidating these compositional challenges and impacts would be an important direction for future research, but this will require more intensive data development and analysis.

\section{b. Health}

For lower income countries like Myanmar, labor is the primary economic asset of the majority of the population. Along with education and skills, health status is an essential labor or human capital quality characteristic. Chronic illnesses, which are many in tropical low-income societies, can reduce 
productivity or completely marginalize adult household members, increasing dependency burdens on already struggling households and small enterprise development. Conversely, improving health standards is essential to rapid and sustained growth, as has been demonstrated over and over again in dynamic Asian economies. At present, Myanmar's health service sector is small relative to the rest of the economy, to the apparent needs of the population, and by comparison to more advanced neighboring economies. While public health data remain fragmentary and of uncertain accuracy, there is evidence of relatively high chronic disease burdens, including endemic tuberculosis, malaria, dengue, and a variety of gastrointestinal parasites. Even though we need much better data on initial conditions and potential for improvement, we have included an indicative scenario to show how increases in health-related labor productivity could support higher and more sustained economic growth (as well as better lives generally).

Like education, the research literature on health and development is extensive (see, e.g., Bloom and Canning 2000, Mayer 2001, Bhargava et al. 2001, and Narayan, Narayan, and Mishra 2010). The approach to establishing causality between health and growth takes two forms: measuring health in terms of productivity or in terms of expenditure on health services. Econometrically, most of the former studies can establish a statistically significant positive link, but the policy challenge is then to devise health policies with defined levels of productivity improvement. For the latter approach, the correlation between health expenditure and growth is much less clear across countries and time. The weakness here appears to be a secondary effect, where expenditures are not sufficient to explain health service effectiveness. It would be easier for policy makers to target expenditure levels, but unfortunately, the real task is to deliver transformative health service. For the present, we do not prescribe detailed institutional reforms, but want simply to measure the growth potential of a healthier Myanmar population. To do this, we accept consensus estimates that improved health status in neighboring economies accelerated average labor productivity growth by about $20 \%$ during their dynamic growth phases.

\section{Infrastructure}

\section{a. Transportation}

Because it confers market access, transportation has long been recognized as one of the essential forms of infrastructure for economic growth. This is particularly true in countries with diverse terrain and large poor rural populations. Most agricultural households in rural Asia live behind real economic and institutional "walls" restricting domestic and transboundary market access. These include high transactions and transport costs, especially for low-income farmers, who are the overwhelming enterprise majority in rural areas. As long as distribution margins remain high, low-income agro-food enterprises with relatively low value products will be prevented from accessing markets. Worse, they are trapped in this low level equilibrium by insufficient savings and incentives to invest in higher value, marketable agrifood products like livestock and nonsubsistence, specialty crops. Conversely, lowering market access costs and related margins can enlarge the horizon of profitable trade for all, increasing commerce, capturing value-added, and promoting self-directed poverty reduction. To assess the significance of these constraints in Myanmar, we construct a scenario where transport costs fall 33\% by 2020 and remain there for the next decade.

\section{b. Energy}

Energy is an essential component of economic activity and an inseparable companion of livelihood improvement. Unfortunately, energy remains scarce in Myanmar, and constraints on its extensive 
deployment are substantial. To assess the systemic importance of this constraint, we conducted a relatively simple scenario that lowers electricity costs 33\% by 2020 against the baseline and keeps them there for the following decade.

\section{c. Telecom/Information Technology}

What was just said for energy holds with at least equal measure for telecom and information technology (IT) services. In this scenario, we reduce the economic scarcity of these growth agents by cutting telecom and IT costs 50\% below baseline by 2020 and keeping them there until 2030 .

It must be emphasized that macroeconomic forecasting, such as the one used here, cannot capture the engineering details of electricity dispatch or telecom/IT distribution logistics. These are major challenges in Myanmar at the moment, with widespread power intermittency and limited IT coverage constituting a significant constraint on day-to-day business activities. Our approach lacks the resolution to identify or solve these problems from an economic policy perspective, but we assume that sustained investments in the sector will limit their long-term importance.

\section{Financial Liberalization}

Another hallmark of successful Asian dynamism, at least in the "second generation" of Asian Tigers and the successors, has been FDI. This phenomenon, pairing external investment with domestic labor, at once overcomes two imbalances. Investors from relatively capital abundant, labor-scarce economies are able to match resources with relatively scarce capital, labor abundant economies in a win-win partnership that enhances returns and growth opportunities for both sides. Beyond this, from the FDI destination perspective, fixed (rather than portfolio) foreign investment usually confers two other significant growth dividends: technology transfer and export market access. In Southeast Asia particularly, this kind of synergy has accelerated growth and modernization with surprising alacrity, promoting skill-intensive development and more rapid transition to self-sustained consumer economies.

Policy makers in Myanmar are of course already well aware of the importance of the opportunity, but experience around the world shows that outcomes depend on many individual conditions. To elucidate the potential for FDI in Myanmar, we construct a generic scenario that permits foreign savings to rise to $6 \%$ of GDP by 2020 and remain there until $2030 .{ }^{3}$ In particular, we do not target the resulting investment, but allow it to be determined by market forces and the complex interaction of commodity prices, factor prices, and productivities.

3 The People's Republic of China, for example, achieved over 7\% during its rapid growth phase. Myanmar's GDP is currently much smaller relative to the available pool of international investment capital. 


\section{Table 2: Scenario Summary}

\begin{tabular}{|c|c|c|}
\hline \multicolumn{3}{|l|}{ Core Growth } \\
\hline 1 & Baseline & $\begin{array}{l}\text { Pre-reform growth rates. We assume this represents historical rates over the last decade, averaging } 4.8 \% \text { per year, with more recent } \\
\text { increases }(5.3 \%, 6 \% \text {, and } 6.2 \% \text { over } 2010-2012) \text { included despite their links to the reforms. }\end{array}$ \\
\hline \multicolumn{3}{|r|}{ ( } \\
\hline 2 & Rice yields & Rice yield growth of $2 \%$ annually, closing half the gap with the highest yields in Asia by 2030. \\
\hline 3 & Diversification & In addition to scenario 2, other agricultural productivity grows by $3 \%$ annually, including other crops and livestock. \\
\hline 4 & Value-added growth & Assumes TFP growth is $50 \%$ higher than scenario 3. \\
\hline Industry & & $\begin{array}{l}\text { In each of the following three scenarios, we assume TFP growth for sector groups comparable to other lower income GMS } \\
\text { economies. }\end{array}$ \\
\hline 5 & Resource based & $\begin{array}{l}\text { Forest products; Fishery and aquaculture; Oil, gas, and coal extraction; Other mineral mining; Paper products and publishing; Refined } \\
\text { petroleum products }\end{array}$ \\
\hline 6 & Light industries & Processed food; Beverages and tobacco; Textiles; Apparel and footwear; Wood products \\
\hline 7 & Manufacturing & Chemical products; Nonmetal minerals; Metal products; Machinery; Transport equipment; Electronics \\
\hline \multicolumn{3}{|l|}{ Services } \\
\hline 8 & Tourism & Hotel, restaurant, and tourist services \\
\hline 9 & Private services & Wholesale and retail trade; Finance, insurance, and real estate; Other private services \\
\hline \multicolumn{3}{|c|}{ Support for Growth } \\
\hline \multicolumn{3}{|l|}{$\begin{array}{l}\text { Human } \\
\text { Development }\end{array}$} \\
\hline & Labor productivity & $\begin{array}{l}\text { Assumes that Myanmar sustains growth rates of labor productivity as indicated in Figure 2, with rates for all countries converging to } \\
\text { the regional average by } 2030 \text {. }\end{array}$ \\
\hline 10 & Education & Improved education induced labor productivity to grow 30\% faster across skill levels by 2030. \\
\hline 11 & Health & Improved health status accelerated average labor productivity growth by about 20\% by 2030 . \\
\hline \multicolumn{3}{|r|}{ P } \\
\hline 12 & Transportation & $\begin{array}{l}\text { In addition to scenario } 4 \text {, assumes that investments and institutional changes effect a } 50 \% \text { reduction in trade, transport, and transit } \\
\text { margins for lower income Asian countries. }\end{array}$ \\
\hline 13 & Energy & Real electricity costs decline $50 \%$ by 2030 . \\
\hline 14 & Telecom/IT & TFP growth in Telecom/IT as scenarios 5-9. \\
\hline 15 & FDI & Assumes that Myanmar's stock of FDI sustains 6\% of GDP to 2030. \\
\hline
\end{tabular}

FDI = foreign direct investment, GMS = Greater Mekong Subregion, IT = information technology, TFP = total factor productivity

Source: Authors. 


\section{RESULTS AND INTERPRETATION}

\section{A. Macroeconomic Results}

As explained in the scenario discussion, our objective here is to identify the potential sources of longterm growth for Myanmar, as these would be realized by a combination of domestic institutional reform and determined commitments to market transition and open multilateralism. Thus, we begin with a pre-reform baseline and add policy scenarios that represent, in each case, different components of a typical dynamic Asian economic system. If Myanmar continues on its current path, the growth effects illustrated in Table 3 are indicative of what can be expected. These show the change for each scenario from the baseline of selected macroeconomic aggregates. From the perspective of real GDP growth (indexed to 100 in 2010), Figure 3 illustrates the impacts of the policies considered.

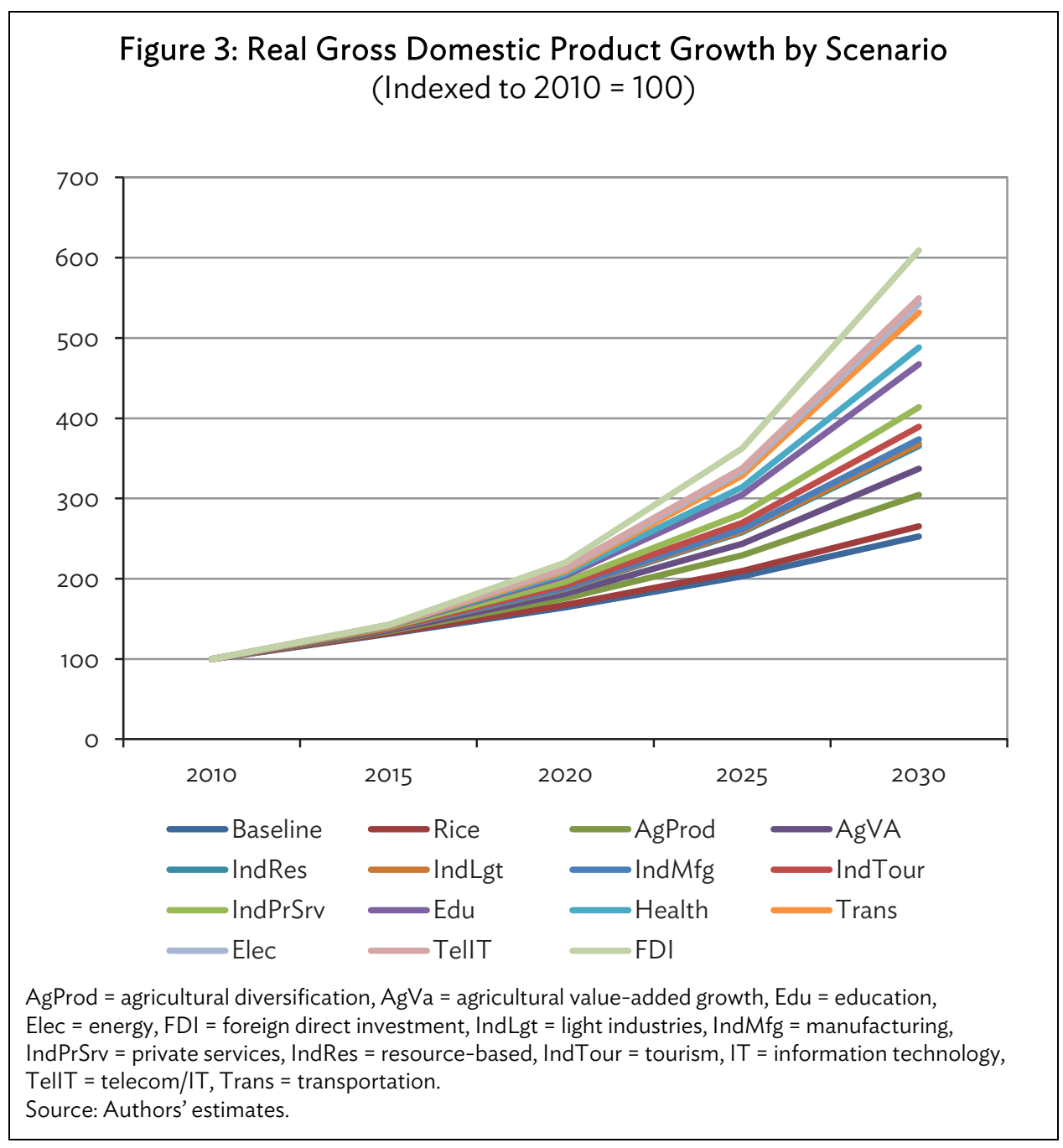


Table 3: Macroeconomic Aggregates

(\% change from baseline in 2030)

\begin{tabular}{lccccccccccccccccccc}
\hline & Rice & AgProd & AgVA & IndRes & IndLgt & IndMfg & IndTour & IndPrSrv & Edu & Health & Trans & Elec & TellT & FDI \\
\hline Real GDP & 5 & 20 & 33 & 45 & 46 & 48 & 54 & 64 & 85 & 93 & 110 & 115 & 117 & 141 \\
HH Real Income & 3 & 12 & 18 & 29 & 30 & 31 & 34 & 40 & 53 & 57 & 80 & 83 & 84 & 108 \\
Real Consumption & 5 & 23 & 36 & 45 & 46 & 48 & 53 & 62 & 78 & 84 & 113 & 118 & 121 & 144 \\
Exports & 3 & 15 & 28 & 42 & 43 & 45 & 50 & 59 & 77 & 84 & 88 & 92 & 94 & 106 \\
Imports & 3 & 14 & 23 & 35 & 36 & 37 & 41 & 48 & 61 & 66 & 93 & 96 & 97 & 135 \\
Real Wage & 0 & 2 & 4 & 10 & 10 & 10 & 11 & 13 & 15 & 16 & 24 & 25 & 25 & 35 \\
Revenue & 3 & 12 & 18 & 29 & 29 & 30 & 33 & 39 & 51 & 56 & 78 & 80 & 81 & 105 \\
Growth Increment & 5 & 16 & 13 & 11 & 1 & 2 & 6 & 10 & 21 & 8 & 17 & 4 & 3 & 24 \\
Real GDP Annual & 5.0 & 5.7 & 6.3 & 6.7 & 6.7 & 6.8 & 7.0 & 7.4 & 8.0 & 8.3 & 8.7 & 8.8 & 8.9 & 9.5 \\
\hline
\end{tabular}

AgProd = agricultural diversification, $\mathrm{AgVa}=$ agricultural value-added growth, Edu = education, Elec = energy, FDI = foreign direct investment, $\mathrm{GDP}=$ gross domestic product, $\mathrm{HH}$ = household, IndLgt = light industries, IndMfg = manufacturing, IndPrSrv = private services, IndRes = resource-based, IndTour = tourism, IT = information technology, TellT = telecom/IT, Trans = transportation.

Notes: Rows 1-7 measure percentage scenario differences from the baseline in 2030. Growth increment is the percent 2030 contribution to real GDP from each scenario, taken in sequence. Row 9 presents the annual average growth of real GDP over the period 2010-2030, for each scenario.

Source: Authors' estimates.

These results make clear the long-term benefits of expanding and deepening the reform process. As the last row of the table indicates, full realization of the economy's potential could take annual growth from more pessimistic levels below $5 \%$ to something comparable to rates the People's Republic of China (PRC) achieved over the last 2 decades. Whether or not this is completely feasible for Myanmar will depend on many factors, both those within the control of policy makers and external to the country, but certainly, policies that reflect the scenario assumptions can be a potent catalyst for growth and livelihoods improvement.

Among other notable characteristics of the macro results is the close relationship between real GDP growth and that of real household income and consumption. This fact is due to the country's relatively closed initial state, which means average growth dividends will be captured at the margin, even if marginal growth is shared with external investment partners. Trade also grows robustly across scenarios, permitting Myanmar to leverage external demand for growth like the classic success stories of the region. As one would expect with a labor surplus economy and relatively low initial labor productivity, wages are slow to rise in the beginning of this (admittedly artificial) sequence of policies, but begin to show substantial appreciation as growth accelerates. A significant part of household income growth is therefore coming from nonlabor assets (land, enterprise capital, etc.), which means property rights will be important to distributional outcomes going forward. 


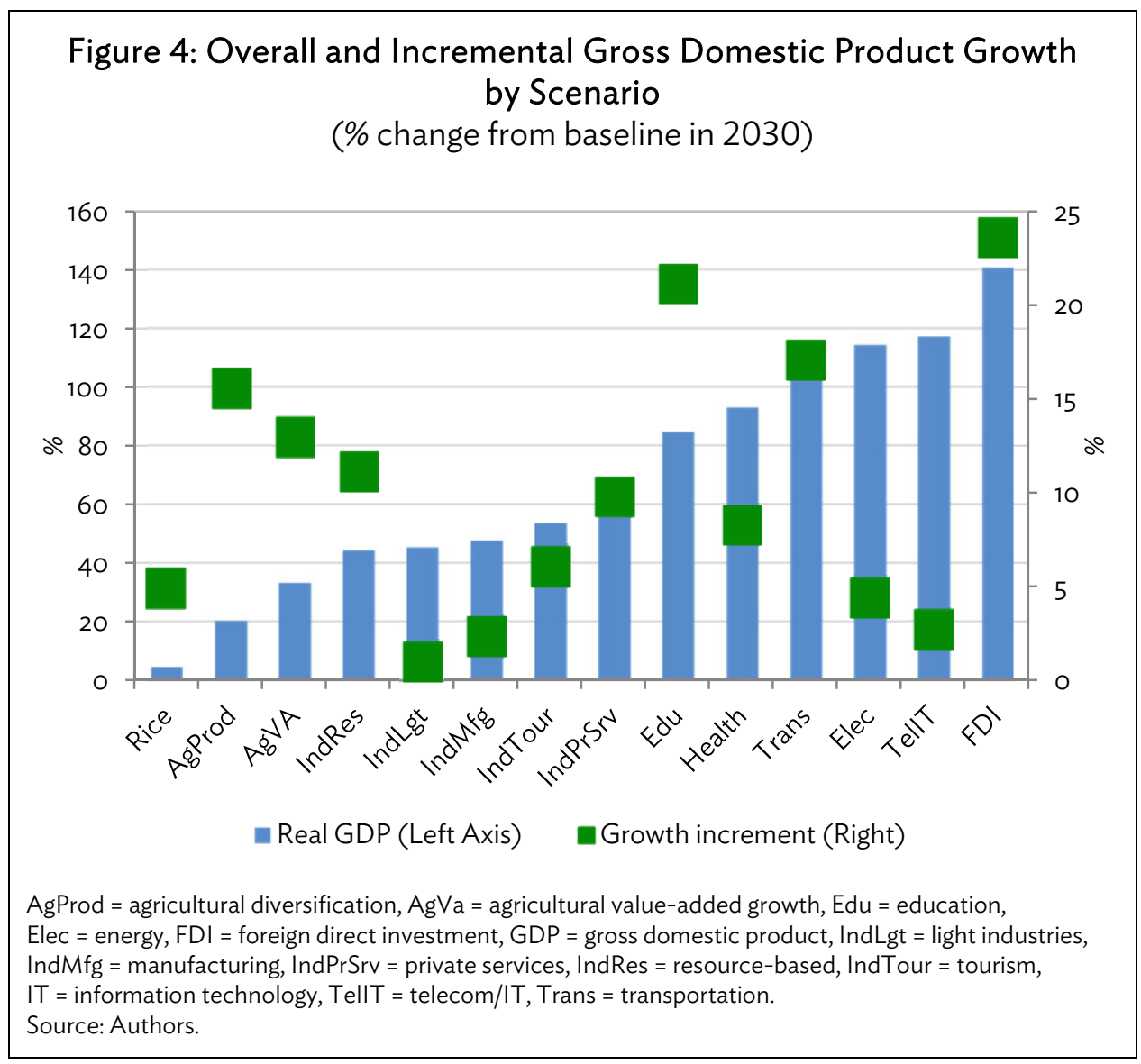

To give some perspective on comparative dynamics, Figure 4 compares overall GDP growth effects with the incremental change due to each scenario (Table 3, Rows 1 and 8, respectively). Of course, these policies will not really be introduced sequentially, and ultimately, it would not be possible to completely disentangle the influences. With this caveat, however, this approach helps elucidate the magnitude that each sector or policy component contributes to the overall growth. Blue columns in the figure are the percent GDP growth against baseline in 2030, just as in Table 3 above. The squares in the figure measure the incremental GDP growth dividend that accrues with each successive scenario (Right Axis).

Each of these impacts is discussed in detail below, but a few general comments are appropriate. The biggest incremental growth benefits are associated with the agriculture sector (excluding rice), human capital improvements, infrastructure, and FDI. In all cases, this corresponds to one of the most serious growth constraints facing Myanmar. In its current (initial) conditions, agricultural factor productivity (and corresponding value-added), overall labor productivity, infrastructure capacity, and domestic savings are all extremely low. Overcoming these growth constraints with higher agrifood productivity, education, infrastructure investment, and foreign savings, respectively, must be a leading priority for the economic transition.

A number of important policy insights emerge from these results. Firstly, expanding capacity in the rice sector may be important for food security, but it should not be overrated for its aggregate growth benefits. Rice is essential, but it is a staple, meaning it has very low income elasticity and, once basic needs are met, will contribute little to demand-driven economic expansion. Of course, rice can 
be an important (and risky) source of export revenue, but as we see in the other scenarios. Myanmar has other dynamic export opportunities that may be more fully integrated with the rest of the economy. Finally, however, it must be recognized that rice is important to rural livelihoods, meaning that judgments on promoting this sector should be reserved until the data are developed to support more detailed distributional analysis.

Of particular interest from the perspective of agriculture is the growth potential from other crops and livestock, as reflected in the agricultural diversification (AgProd) scenario. When these product categories are added, their higher income elasticities allow the rural sector to participate more fully in urban and indeed regional growth. It should be recalled that this was the secret of early agriculture reforms in the PRC. When Chinese farmers were allowed to make their own production and marketing decisions, they immediately diversified from cereals to specialty products, particularly fruits, vegetables, and livestock. The result, the largest wealth transfer (from urban consumers to farmers) in modern Chinese history, dramatically improved rural livelihoods and gave essential political support to the overall reform process. In any case, it is clear that agrifood diversification can significantly improve Myanmar's aggregate growth potential.

Asian growth over the last two generations has witnessed an interesting hierarchical development of agrifood supply chains. Early growth economies, as their economies modernize and incomes increased, have outsourced agrifood production with a combination of simple contracting and more complex supply chain relationships. The latter usually entailed significant overseas investment and technology transfer, which helped many lower income regional partners accelerate value-added creation in their own food systems. Thailand is only one example, but the history of its agrifood linkages to Japan and the Republic of Korea has been an important part of its superior aggregate growth and agrifood sector performance. The agricultural value-added growth (AgVA) scenario simulates a similar process in Myanmar, and the incremental contribution of such a process is significant. Given the relatively early stage of Myanmar's food processing sector development, the upside potential estimated here is probably quite conservative.

Turning to industrial sector development, the component results for aggregate growth might be seen as disappointing. Incremental contributions here are less than they could be for three reasons. The first two could be associated with readiness, i.e., the present condition of two essential industrial growth drivers, Myanmar's labor productivity and domestic savings resources. While human potential is vast in this country, education and skill levels remain low by regional standards. In terms of domestic investible capital, Myanmar has begun the reform process with relatively low domestic savings, and much of these are currently tied up in property assets. ${ }^{4}$ Thirdly, it must be kept in mind that Myanmar's economy is emerging in a very competitive regional environment, particularly in these industrial categories, and taking its place at the lower end of the skill and technology ladder will not confer the same benefits as mobilizing higher technology industries. As we shall see below, when labor productivity rises with education, and savings constraints are relaxed with FDI, these sectors are animated with new competitiveness and make substantial contributions to overall growth.

Service sectors offer more promising growth dividends, particularly given Myanmar's initial conditions. Because these are relatively less skilled and capital intensive, and more widely distributed

4 For comparison, the PRC began its economic reform process with a savings rate of 35\% of GDP, facilitating public and private capital investments from the outset. Viet Nam, after two generations of conflict, had a much lower savings rate, at about $5 \%$ in the early 1990s, and was much more reliant on external savings for growth. The baseline assumption for Myanmar is about $10 \%$, based on the average of pre-reform period in the 2000 s. 
across the economy, they may be more appropriate for local private investment and public sector facilitation. While dynamic industrial development will probably require longer-term commitments to skill development and external investment partnerships, service sector development can expand immediately and more uniformly across the economy, making substantial contributions to growth in the process.

Human capital has, in many ways, been the primary impetus of sustained growth in dynamic Asian economies. Establishing long-term competitive advantages in the global economy has certainly required investment in private and public assets, but the human capital oriented, skill-intensive mode of development is probably what most distinguishes Asia's export successes from the experience of other emerging regions. In the most successful cases, it has underwritten an emergent middle class and transition to robust and sustained Keynesian growth from domestic demand, while economies in other regions remain at the mercy of commodity cycles, destabilizing inequality, and chronic urban poverty traps.

In the education (Edu) scenario, we can see that similar benefits could accrue to Myanmar. Labor is an essential input in nearly every sector of the economy, and more productive labor would enhance growth potential likewise. Of course, this takes time, and Myanmar is beginning with a double challenge in this area. Not only is existing educational infrastructure and attainment very unequal and low by regional standards, but a legacy of this has created an "unskilled middle" in the labor market consisting of workers beyond traditional school age but with very low attainment levels. Overcoming this national skill deficit will require patience and education and training reforms that can accelerate school expansion and attainment while at the same time reaching out to older workers with vocational development strategies. The current scenario is simplified indeed, but it reinforces the essential lesson that public and private investments in human capital must proceed in parallel. Even if extensive education reform and refinancing are needed to accomplish this, the benefits for the overall economy are enormous, with incremental stimulus of over $20 \%$ to long-term (2030) GDP.

Health status is a second major determinant of labor productivity; although somewhat weaker in its estimated economic impact, it still supports 10\% higher real GDP growth and thus, could be largely self-financing (Organisation for Economic Co-operation and Development [OECD] countries spend $7 \%-8 \%$ of GDP on health, while Myanmar currently commits 1\%). It should also be emphasized that economic benefits of a healthier population are less in the initial, low skill and low-income stages of development, but they can rise dramatically with income and technical progress.

Infrastructure is of course essential to growth, and transport infrastructure, particularly so. Expanding road, rail, and other transport networks can have economic benefits that are startling both in their magnitude and distribution. Because they lower the costs of market access for most actual and would be participants, transport assets expand the horizon of profitability for investment wherever they go. Just as importantly, the benefits of this public commitment are compounded by private agency, as individuals and enterprises leverage enhanced market access with their own investments to expand activity. The result is a contagion of economic networks that has long been at the heart of dynamic growth policy. The transportation (Trans) scenario captures both the intent and the impacts of this, reflecting a 33\% reduction in average domestic transport costs and the sharp aggregate growth dividend this would confer. In fairness, much of the benefit attributed here to transportation actually belongs to some of the industry promotion scenarios that were already discussed, but of course, they cannot reach their full potential until market access is improved. 
Results for the other two infrastructure sectors, electricity (Elec) and telecom/IT(TellT), must be interpreted with care. The productivity of both energy and information services are obvious intuitively, but notoriously difficult to measure. In the case of energy, there really is no simple counterfactual comparing, e.g., transport with and without this input. Likewise, IT and telecom services are so completely embodied in economic activities that their "marginal product" really cannot be decomposed. Suffice to say that lower electricity prices would promote growth in Myanmar, as would higher IT services, but these do not appear to be significant binding constraints relative to others. The main issue with electric power is an absolute one (availability), not a matter of some percentage price difference. If the extent and reliability of service could be substantially improved, the impact would look more like that for transportation. Also, as emphasized in the scenario section, we are modeling very long-term relationships between infrastructure and growth. A macroeconomic model like this one cannot capture the current logistical issues in Myanmar related to electric power intermittency and fragmented IT coverage. These are seen by most observers to be transitory, and for this reason, our estimates should be interpreted as trends rather than short-term predictions.

Finally, the FDI scenario completes the "puzzle" of Asian dynamic growth for Myanmar. As a country with relatively low domestic savings resources, self-financed public and private investment would take a long time to meet the standards that have been established elsewhere, with more open multilateral financial strategies. For lower income economies, FDI and the partnership that accompanies it confer a "Holy Trinity" of benefits: external savings for domestic investment, technology transfer, and export market access. These three advantages have changed the entire growth dynamic of other economies in the region, and we can see from these results that the same opportunity awaits Myanmar. In truth, this scenario only measures the external savings benefit, while the other two contributions of FDI would facilitate productivity growth and export expansion already embodied in earlier scenarios.

\section{B. Structural Results}

The principal focus of this report, a preliminary application of a new decision support tool for Myanmar's economic policy, is on long-term macroeconomic aggregates. However, underlying these trends is a complex structural framework that can shed light on more detailed growth drivers and impacts. As such, the model will be extended as higher resolution data become available to support more specific targeting of policies, as well as identification of more detailed patterns of growth opportunities and adjustment challenges.

For the sake of illustration, we include a few examples in the present report. Consider Figure 5, which illustrates growth dynamics for all 32 sectors of the Myanmar CGE model. Baseline (average annual) growth rates of value-added are measured on the vertical axis, while the horizontal axis measures corresponding growth rates for the most dynamic scenario considered, FDI. It is plainly evident from these results that different economic activities will respond differently to the policies considered. All sectors grow more rapidly under the FDI scenario, but some are more responsive to the policies considered than others. Having said this, it should be noted that most sectors cluster in a relatively high-growth group. When open financial markets prevail, allocation of investment funds will be such as to equalize returns, and thereby access growth prospects, across sectors. 


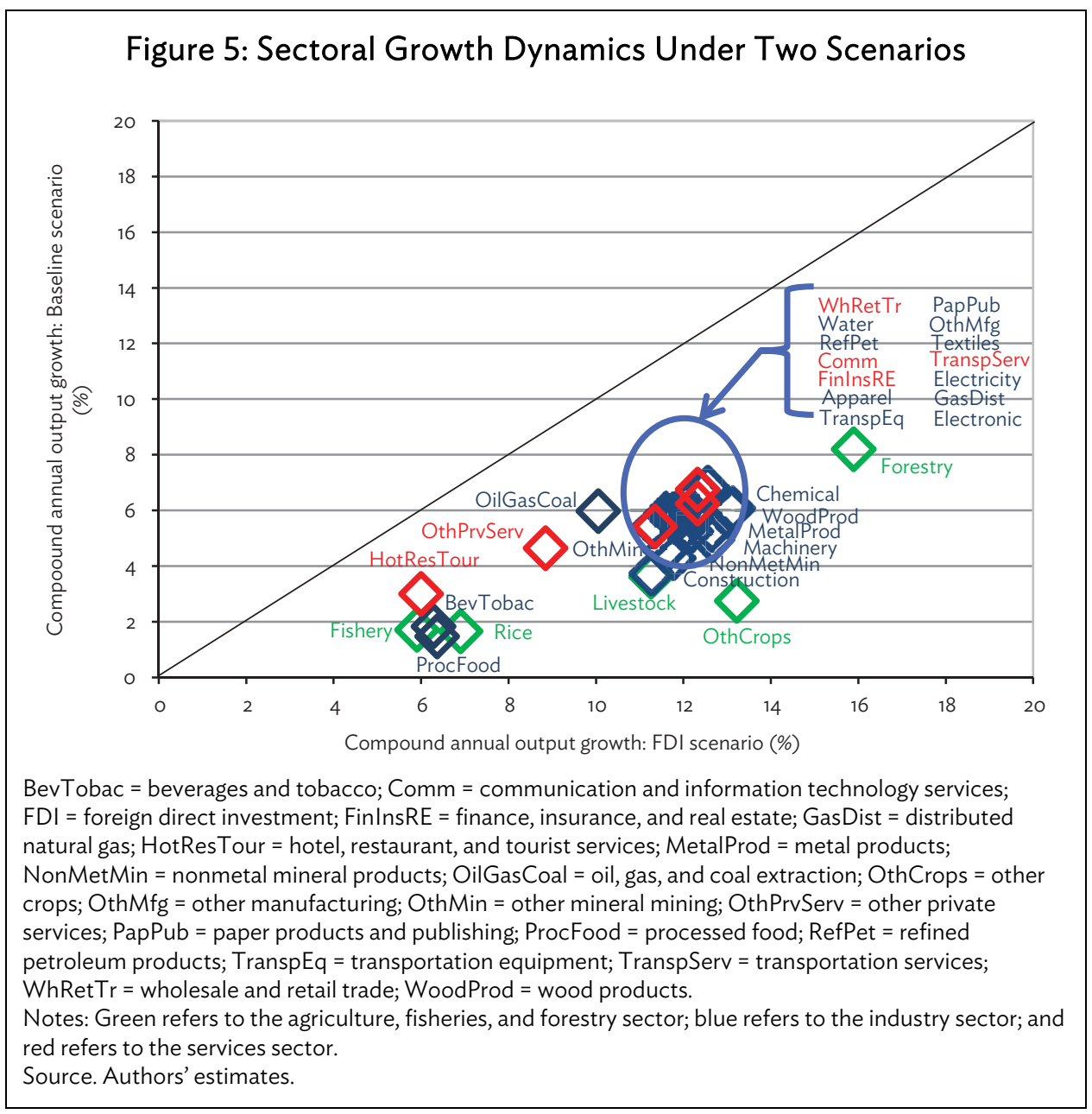

\section{Labor Markets, Employment, and Migration}

The macroeconomic results above are dramatic because of Myanmar's growth potential, but even these numbers understate the degree of structural change that the economy will experience. Beneath the smooth veneer of macroeconomic aggregates, resource shifts across economic activities generally are much more significant. One important indicator of structural change is employment patterns, as labor is reallocated across activities according to comparative advantage, skills, and relative wages. Although the current labor force data we have for Myanmar must be considered as preliminary, we can offer some indicative results to illustrate the forces of economic restructuring that will follow from reforms and other events included in our scenarios.

Table 4 presents a simple breakdown of changes in long-term rural sector employment by agricultural activity. These results are precisely what one would expect, reflecting the near universal process by which agrifood modernization leads to rural-urban transition. In the first scenario, improvement in rice productivity liberates workers to look for employment elsewhere, including support for agricultural diversification (toward higher value crops and livestock) and migration to urban employment in industry and services. When productivity gains are extended to other agrifood sectors (Scenario 2), livestock labor needs fall dramatically as well, permitting further rural-urban migration and diversification toward agrifood products with higher income elasticities (specialty vegetables, fruits, and higher value export crops). 
Table 4: Sectoral Employment Impacts

(\% change from baseline in 2030)

\begin{tabular}{lrrrrrrrrrrrrrr}
\hline & \multicolumn{1}{c}{ Rice AgProd IndRes } & AgVA & IndLgt & IndMfg & IndTour IndPrSrv & Edu & Health & Trans & Elec TellT FDI \\
\hline Rice & -56 & -47 & -62 & -62 & -61 & -61 & -60 & -59 & -58 & -57 & -54 & -53 & -53 & -51 \\
Other crops & 7 & 10 & 39 & 50 & 40 & 40 & 41 & 44 & 46 & 47 & 58 & 59 & 59 & 54 \\
Livestock & 12 & -30 & -42 & -45 & -41 & -41 & -39 & -37 & -32 & -31 & -20 & -19 & -19 & -12 \\
Forestry & 4 & 15 & 42 & 19 & 44 & 47 & 55 & 62 & 88 & 99 & 111 & 116 & 116 & 163 \\
Fishery & 5 & 15 & 15 & 20 & 15 & 16 & 16 & 17 & 18 & 18 & 22 & 22 & 23 & 20 \\
Manufactures & 4 & 11 & 17 & 10 & 18 & 18 & 22 & 28 & 39 & 43 & 48 & 50 & 51 & 54 \\
Services & 5 & 17 & 31 & 24 & 31 & 33 & 35 & 39 & 51 & 55 & 74 & 76 & 77 & 98 \\
Grand total & 3 & 9 & 19 & 15 & 20 & 21 & 23 & 28 & 38 & 41 & 54 & 55 & 56 & 67 \\
\hline
\end{tabular}

AgProd = agricultural diversification, AgVa = agricultural value-added growth, Edu = education, Elec = energy, FDI = foreign direct investment, IndLgt = light industries, IndMfg = manufacturing, IndPrSrv = private services, IndRes = resource-based, IndTour = tourism, IT = information technology, TellT = telecom/IT, Trans = transportation.

Source: Authors' estimates.

On the receiving end of this large-scale migration process, net of within-ag labor reallocation, are the nonfarm rural and urban labor markets, represented in the Manufactures and Services sector rows of Table 4. Here we see the consequences of a classic structural transition from a predominantly agrarian labor economy to a mixed manufacturing and tertiary economy, powered jointly by combined agricultural productivity growth and robust expansion of the urban sector, higher skill, and real wage employment. The demand side of this labor market restructuring is in turn driven by the policy reforms embodied in the generic scenarios we have considered. The net result for Myanmar is a dramatic increase in total employment. This is possible, even though we do not consider an increase in overall population growth, because we have assumed that extensive surplus and informal labor existed initially, in accordance with present day Myanmar conditions and those of comparable economies at the early stages of modernization.

These estimates are based on very preliminary labor market data, and more determined labor data development and analysis can improve our understanding of the opportunities and policy challenges needs to achieve this kind of economy-wide growth. Having said this, however, the macroeconomic restructuring process seen here is fully consistent with that of successful dynamic economies elsewhere in the region. Reforms can achieve the momentum of enterprise development in the nonfarm labor market, while agrifood productivity gains can release the needed labor resources to meet this rapidly emerging demand. The aggregate employment dividends (last column of Table 4), rising by up to $77 \%$, represents the true potential of the country's human resources, and every effort should be made to achieve this for the sake of nationwide poverty reduction, inclusive economic growth, and more complete regional economic integration.

\section{Demographic Transition}

Another important structural characteristic of the Myanmar economy relates to demographics. As human capital is essential to growth, so are the age and skill structures of the population and labor force essential to the productivity of human capital. Myanmar has complex demographics, and these in turn bear upon the eligibility of the population for productivity enhancing investments like education and training. Figure 6 shows how the population age structure will evolve over the scenario period 
being considered. This profile is familiar from other Asian economies, which begin growth with an expanding able-bodied population (falling dependency) followed by an aging trend that increases dependency. Whether or not the aging trend reverses itself in the later stages of rapid growth, as we see in these United Nations forecasts, is a preoccupation of many higher income Asian economies today.

For Myanmar, as other experts have emphasized, the demographic transition is complicated significantly by the initial skill composition of the labor force. Although numerical dependency rates are falling, a large share of the working adult population has relatively low productivity and may have difficulty improving this with conventional educational and training systems. In order to take full advantage of all its economically eligible population, building a basis for future growth and their own late life economic security, more innovative education and training models may have to be deployed over the next 2 decades.

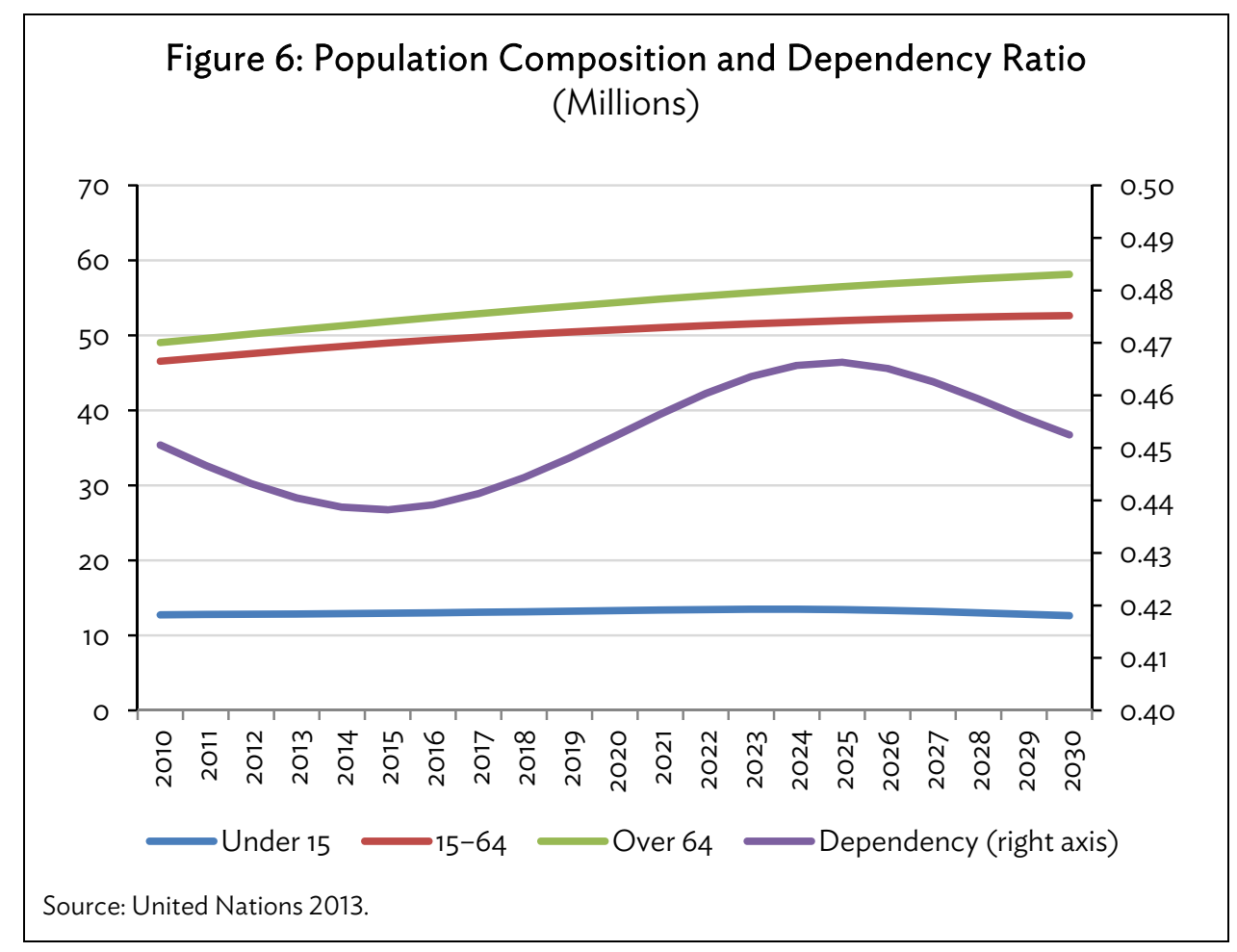

\section{CONCLUSIONS}

The new Myanmar forecasting model represents a decision support tool with an extensive range of policy application. As demonstrated in this paper, macroeconomic projections can be made on the basis of ex ante policy assumptions about detailed structural characteristics of the economy, changing external events, and a wide array of policy strategies. To be more effective, however, the informational basis of the model must be further strengthened, expanded, and deepened.

Using a new dynamic forecasting model, we assessed the long-term benefits of sustained economic reforms for the Myanmar economy. These results suggest that there is a broad horizon of opportunity for promoting rapid and inclusive economic growth, but determined commitments will be needed to public investment, human capital development, and facilitation of domestic and 
international private agency. On its current path of domestic reform, the government of Myanmar can advance all these essential growth drivers, maintaining a stable macroeconomic environment that is conducive to private investment, market development, and regional economic integration.

In addition to a favorable investment climate, the government needs a balanced approach to sector interests to promote inclusive and equitable growth. Promoting agricultural productivity, for example, will not only benefit the rural poor majority, but also release labor resources to facilitate industrial and service sector development. Conversely, secondary and tertiary development will facilitate agrifood supply chain development, improving market access and real incomes in rural areas. Generalized public commitments to infrastructure, education, and public health will, if targeted equitably, make the most sustained contribution to realizing Myanmar's vast economic potential. 


\section{APPENDIX 1: MODEL SUMMARY}

This paper uses a single country prototype CGE model whose formal structure has been applied to over 50 countries. The base data set, a new SAM for Myanmar estimated by the authors, is calibrated for 2010 across 32 economic sectors. The current version of the SAM has five factors of production (skilled and unskilled labor, capital, land, and natural resources), one nationally representative household, and a single (rest of the world) trading partner. The sectoral definitions can be found in Table A1.1 below. The remainder of this section outlines briefly the main characteristics of supply, demand, and the policy instruments of the model.

\section{A. Production}

All sectors are assumed to operate under constant returns to scale and perfect competition. Production in each sector is modeled by a series of nested constant elasticity of substitution (CES) production functions that are intended to represent the different substitution and complementarity relations across the various inputs in each sector. There are material inputs that generate the input/output table, as well as factor inputs representing value-added.

Three different production archetypes are defined in the model_crops, livestock, and all other goods and services. The CES nests of the three archetypes are graphically depicted in Figures A1.1 through A1.3. Within each production archetype, sectors will be differentiated by different input combinations (share parameters) and different substitution elasticities. Share structures are largely determined by base year data, and the elasticities are given values by the modeler.

The key feature of the crop production structure is the substitution between intensive cropping versus extensive cropping, i.e., between fertilizer and land (Figure A1.1). Livestock production captures the important role played by feed versus land, i.e., between ranch- versus range-fed production (Figure A1.2). Production in the other sectors more closely matches the traditional role of capital/labor substitution, with energy introduced as an additional factor of production (Figure A1.3).

In each period, the supply of primary factors-capital, labor, and land-is usually predetermined. However, the supply of land is assumed to be sensitive to the contemporaneous price of land. Land is assumed to be partially mobile across agriculture sectors. Given the comparative static nature of the simulations that assume a longer-term horizon, both labor and capital are assumed to be perfectly mobile across sectors (though not internationally).

The current model specification has an innovation in the treatment of labor resources. The Global Trade Analysis Project (GTAP) data set identifies two types of labor skills-skilled and unskilled. Under the standard specification, both types of labor are combined together in a CES bundle to form aggregate sectoral labor demand, i.e., the two types of labor skills are directly substitutable. In the new specification, a new factor of production has been inserted, which we call human capital. It is combined with capital to form a physical cum human capital bundle, with an assumption that they are complements. On input, the user can specify the percentage of the skilled labor factor to allocate to the human capital factor.

Once the optimal combination of inputs is determined, sectoral output prices are calculated assuming competitive supply (zero-profit) conditions in all markets. 
Table A1.1: Sectors for the 2010 Myanmar Social Accounting Matrix

\begin{tabular}{|c|c|c|}
\hline No. & Label & Definition \\
\hline 1 & Rice & Paddy rice \\
\hline 2 & OthCrops & Other crops \\
\hline 3 & Livestock & Livestock \\
\hline 4 & Forestry & Forest products \\
\hline 5 & Fishery & Fishery and aquaculture \\
\hline 6 & OilGasCoal & Oil, gas, and coal extraction \\
\hline 7 & OthMin & Other mineral mining \\
\hline 8 & ProcFood & Processed food \\
\hline 9 & BevTobac & Beverages and tobacco \\
\hline 10 & Textiles & Textiles \\
\hline 11 & Apparel & Apparel and footwear \\
\hline 12 & WoodProd & Wood products \\
\hline 13 & PapPub & Paper products and publishing \\
\hline 14 & RefPet & Refined petroleum products \\
\hline 15 & Chemical & Chemical products \\
\hline 16 & NonMetMin & Nonmetal mineral products \\
\hline 17 & MetalProd & Metal products \\
\hline 18 & Machinery & Machinery \\
\hline 19 & TranspEq & Transport equipment \\
\hline 20 & Electronic & Electronics \\
\hline 21 & OthMfg & Other manufacturing \\
\hline 22 & Electricity & Electric power \\
\hline 23 & GasDist & Distributed natural gas \\
\hline 24 & Water & Water supply \\
\hline 25 & Construction & Construction \\
\hline 26 & TranspServ & Transportation services \\
\hline 27 & Comm & Communication and IT services \\
\hline 28 & WhRetTrade & Wholesale and retail trade \\
\hline 29 & FinlnsRE & Finance, insurance, and real estate \\
\hline 30 & PubAdmin & Public administration \\
\hline 31 & HotResTour & Hotel, restaurant, and tourist services \\
\hline 32 & OthPrvServ & Other private services \\
\hline
\end{tabular}

Source: Authors.

\section{B. Consumption and Closure Rules}

All income generated by economic activity is assumed to be distributed to a single representative household. The single consumer allocates optimally his or her disposable income among the consumer goods and saving. The consumption/saving decision is completely static: saving is treated as a "good" 
and its amount is determined simultaneously with the demands for the other goods, the price of saving being set arbitrarily equal to the average price of consumer goods.

Government collects income taxes, indirect taxes on intermediate and final consumption, taxes on production, tariffs, and export taxes and/or subsidies. Aggregate government expenditures are linked to changes in real GDP. The real government deficit is exogenous. Closure therefore implies that some fiscal instrument is endogenous in order to achieve a given government deficit. The standard fiscal closure rule is that the marginal income tax rate adjusts to maintain a given government fiscal stance. For example, a reduction or elimination of tariff rates is compensated by an increase in household direct taxation, ceteris paribus.

Each region runs a current account surplus (deficit) that is fixed (in terms of the model numéraire). The counterpart of these imbalances is a net outflow (inflow) of capital, subtracted from (added to) the domestic flow of saving. In each period, the model equates gross investment to net saving (equal to the sum of saving by households, the net budget position of the government, and foreign capital inflows). This particular closure rule implies that investment is driven by saving. The fixed trade balance implies an endogenous real exchange rate. For example, removal of tariffs, which induces increased demand for imports, is compensated by increasing exports, which is achieved through a real depreciation.

\section{Foreign Trade}

The world trade block is based on a set of bilateral flows. The basic assumption is that imports originating in different regions are imperfect substitutes (Figure A1.4). Therefore in each region, total import demand for each good is allocated across trading partners according to the relationship between their export prices. This specification of imports-commonly referred to as the Armington specification-implies that each region faces a downward sloping demand curve for its exports. The Armington specification is implemented using two CES nests. At the top nest, domestic agents choose the optimal combination of the domestic good and an aggregate import good consistent with the agent's preference function. At the second nest, agents optimally allocate demand for the aggregate import good across the range of trading partners.

The bilateral supply of exports is specified in parallel fashion using a nesting of constant elasticity of transformation (CET) functions. At the top level, domestic suppliers optimally allocate aggregate supply across the domestic market and the aggregate export market. At the second level, aggregate export supply is optimally allocated across each trading region as a function of relative prices.

Trade variables are fully bilateral and include both export and import taxes and/or subsidies. Trade and transport margins are also included; therefore, world prices reflect the difference between free on board (FOB) and cost, insurance and freight (CIF) pricing.

\section{Prices}

The CGE model is fully homogeneous in prices, i.e., only relative prices are identified in the equilibrium solution. The price of a single good, or of a basket of goods, is arbitrarily chosen as the anchor to the price system. The price (index) of the manufacturing value-added has been chosen as the numéraire, and is set to 1 . 


\section{E. Elasticities}

Production elasticities are relatively standard and are available from the authors. Aggregate labor and capital supplies are fixed, and within each economy, they are perfectly mobile across sectors.

\section{F. Equivalent Variation Aggregate National Income}

Aggregate income gains and/or losses summarize the extent to which trade distortions are hindering growth prospects and the ability of economies to use the gains to help those whose income could potentially decline.

Real income is summarized by Hicksian equivalent variation (EV). This represents the income consumers would be willing to forego to achieve postreform well-being $\left(u^{p}\right)$ compared to baseline well-being $\left(u^{b}\right)$ at baseline prices $\left(p^{b}\right)$ :

$$
E V=E\left(p^{b}, u^{p}\right)-E\left(p^{b}, u^{b}\right)
$$

Here $E$ represents the expenditure function to achieve utility level $u$ given a vector of prices $p$ (the $b$ superscript represents baseline levels, and $p$ the postreform levels). The model uses the extended linear expenditure system (ELES), which incorporates savings in the consumer's utility function. The discounted real income uses the following formula:

$$
C E V=\sum_{t=2005}^{2015} \beta^{(t-2004)} E V_{t}^{a} / \sum_{t=2005}^{2015} \beta^{(t-2004)} Y_{t}^{d}
$$

In this case CEV is the cumulative measure of real income (as a percent of baseline income), $\beta$ is the discount factor (equal to $1 /(1+r)$ where $r$ is the subjective discount rate), $Y^{d}$ is real disposable income, and $E V^{a}$ is adjusted equivalent variation. The adjustment to $E V$ extracts the component measuring the contribution of household saving, since this represents future consumption. Without the adjustment, the EV measure would be double counting. The saving component is included in the $E V$ evaluation for the terminal year. Similar to the OECD, a subjective discount rate of $1.5 \%$ is assumed in the cumulative expressions.

\section{G. Specification of Endogenous Productivity Growth}

Productivity in manufacturing and services is the sum of three components:

i. a uniform factor used as an instrument to target gross domestic product growth in the baseline simulation;

ii. a sector-specific fixed shifter which allows for relative differentials across sectors (for example, manufacturing productivity two percentage points higher than productivity in the services sectors); and

iii. a component linked to sectoral openness as measured by the export-to-output ratio. 
The openness component takes the following functional form:

$$
\gamma_{i}^{e}=\chi_{i}^{0}\left(\frac{E_{i}}{X_{i}}\right)^{\eta}
$$

The parameter $\gamma^{\varepsilon}$ is the growth in sectoral productivity due to the change in openness, $\chi^{0}$ is a calibrated parameter, $E$ and $X$ represent, respectively, sectoral export and output, and $\eta$ is the elasticity. The parameter $\chi^{0}$ has been calibrated so that (on average) openness determines roughly $40 \%$ of productivity growth in the baseline simulation, and the elasticity has been set to 1 .

In agriculture, productivity is fixed in the baseline, set to $2.5 \%$ per annum in most developing countries. However, a share of the fixed productivity is attributed to openness, using Equation (1).

In the baseline, GDP growth is given. Agricultural productivity is similarly given, and Equation (1) is simply used to calibrate the shift parameter, $\chi^{0}$, so that a share of agricultural productivity is determined by sectoral openness. Average productivity in the manufacturing and services sectors is endogenous and is calibrated in the baseline to achieve the given GDP growth target. The economy-wide (excluding agriculture) productivity parameter is endogenous. Equation (1) is used to calibrate the same parameter, under the assumption that some share of sectoral productivity is determined by openness, for example $40 \%$.

In policy simulations, the economy-wide productivity factor, along with other exogenous productivity factors (sector-specific shifters) are held fixed, but the openness-related part of productivity is endogenous and responds to changes in the sectoral export-to-output ratio. In the manufacturing and services sectors, the elasticity is set at 1 . In the agriculture sector, it is set to 0.5.

Say sectoral productivity is $2.5 \%$, and that $40 \%$ of it can be explained by openness, i.e., $1.0 \%$, with the residual $1.5 \%$ explained by other factors. Assume sectoral openness increases by $10 \%$. If the elasticity is 1 , this implies that the openness-related productivity component will increase to $1.1 \%$ and total sectoral productivity will increase to $2.6 \%$ (implying that the total sectoral productivity increases by $4 \%$ with respect to the $10 \%$ increase in sectoral openness). 


\section{Figure A1.1: Production Function for Crops}

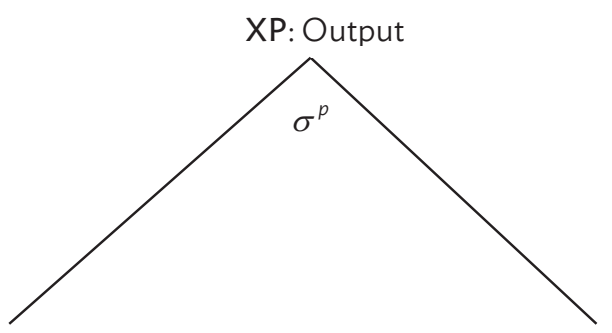

ND: Aggregate intermediate demand

VA: Value-added plus energy and fertilizer

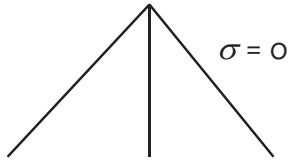

XAp: Intermediate demand

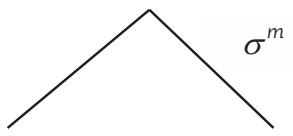

XMT: Aggregate import demand

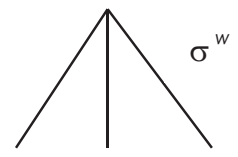

Demand by region of origin

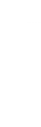

XD: Demand for domestic goods

Unskilled

$\mathrm{AL}$ : Labor demand
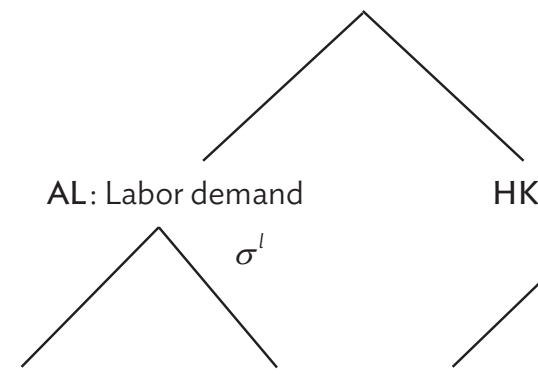

HKTEF bundle

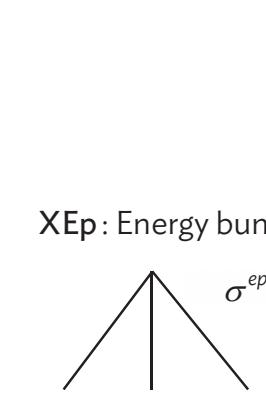

Skilled

HKTE bundle
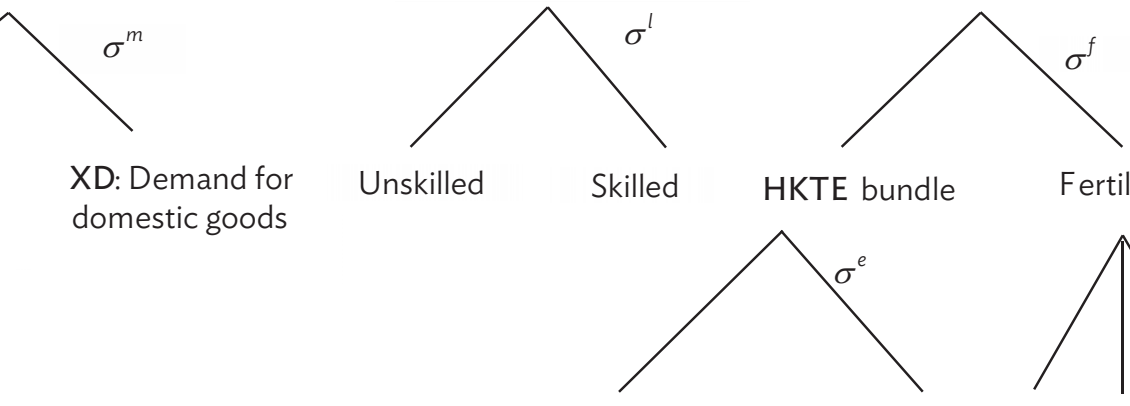

By type of energy

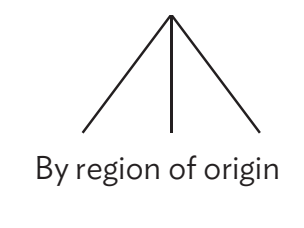

By region of origin

Highly skilled

HKT bundle

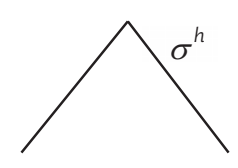

By type of fertilizer and region of origin

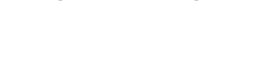

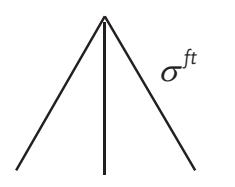
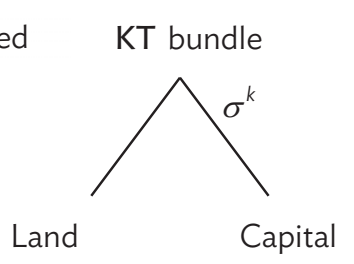

$\mathrm{AL}=$ aggregate labor demand; $\mathrm{HKT}=$ demand for skill-intensive (high tech) capital, other capital and land; $\mathrm{HKTE}=$ demand for nonlabor factors other than fertilizer; HKTEF = demand for nonlabor factors of production; KT = demand for other capital and land; ND = demand for intermediate goods/services by origin; $V A=$ value-added; $X A p=$ intermediate demand by destination; $X D=$ demand for domestic goods; $X E p=$ demand for energy by sector; $X M T$ = demand for imports; $X P=$ sector real output. Source: Authors. 
Figure A1.2: Production Function for Livestock

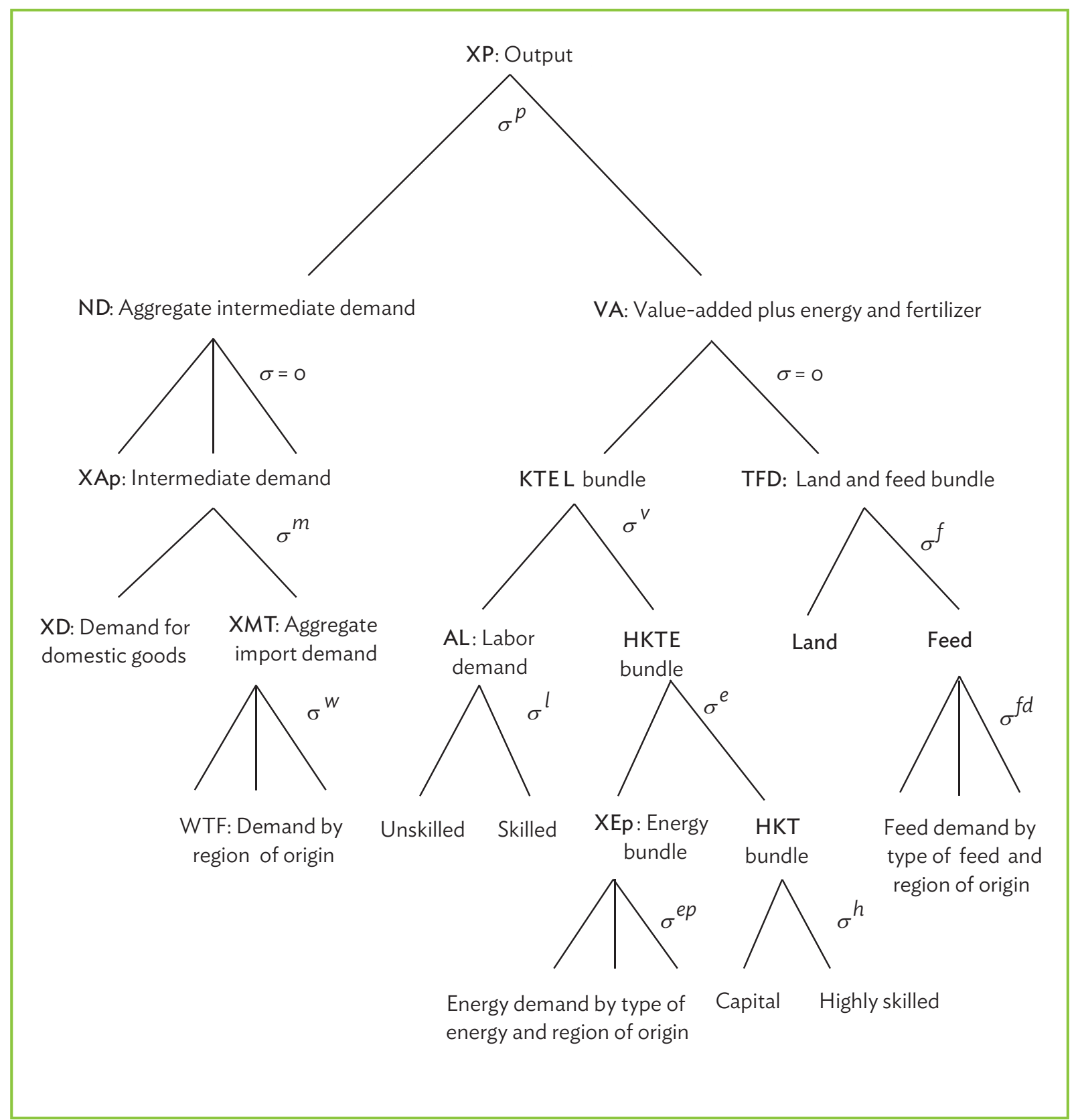

$\mathrm{AL}=$ aggregate labor demand; $\mathrm{HKT}=$ demand for skill-intensive (high tech) capital, other capital and land; HKTE = demand for nonlabor factors other than fertilizer; HKTEF = demand for nonlabor factors of production; KTEL = demand for capital, labor, energy, and labor; ND = demand for intermediate goods/services by origin; TFD = demand for land and animal feed; $V A=$ value-added; WTF = trade in final goods; $X A p=$ intermediate demand by destination; $X D=$ demand for domestic goods; $X E p=$ demand for energy by sector; $X M T=$ demand for imports; $X P=$ sector real output.

Source: Authors. 
Figure A1.3: Production Function for Non-agriculture

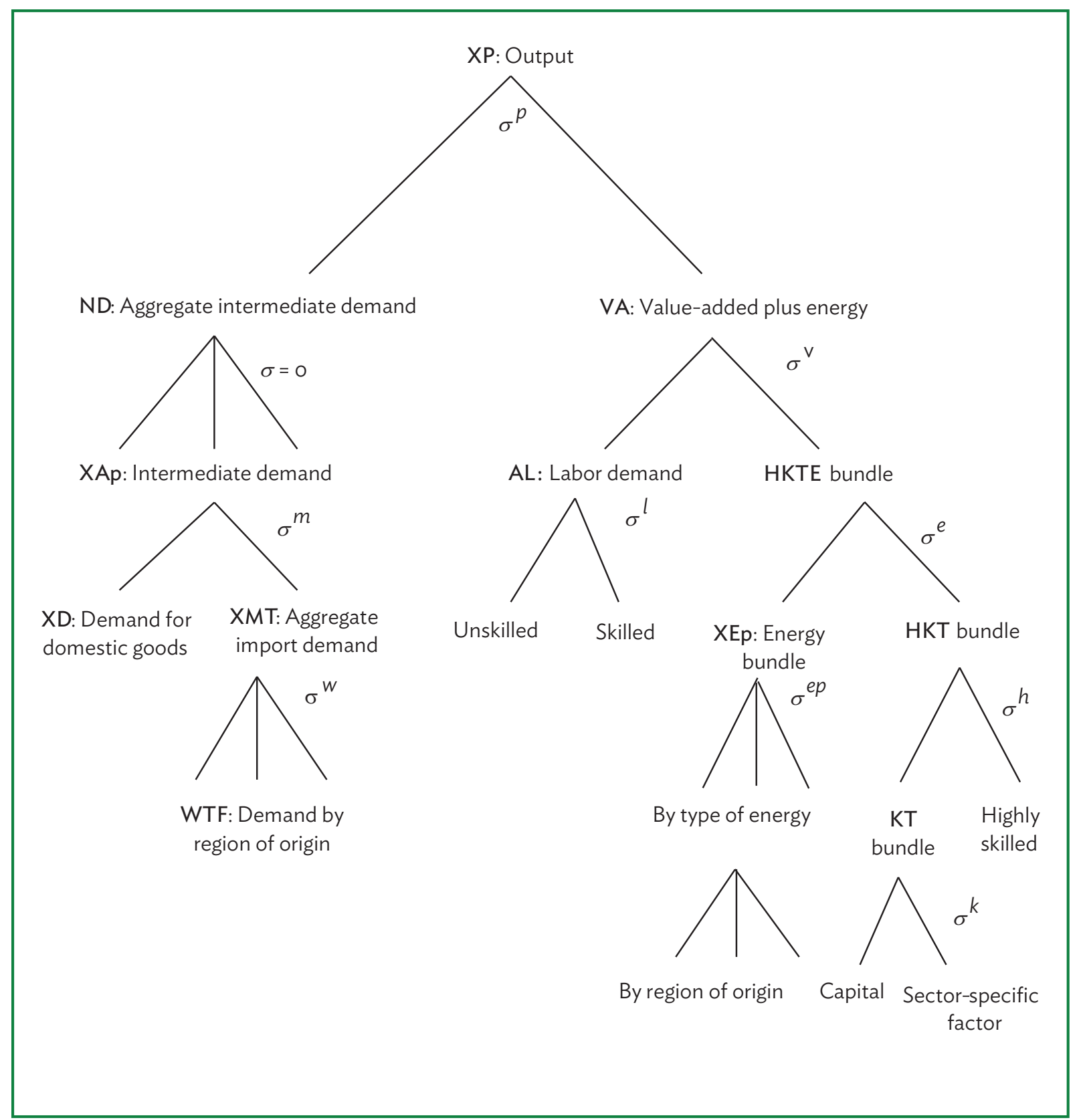

$\mathrm{AL}=$ aggregate labor demand; $\mathrm{HKT}=$ demand for skill-intensive (high tech) capital, other capital and land; $\mathrm{HKTE}=$ demand for nonlabor factors other than fertilizer; $\mathrm{KT}=$ demand for other capital and land; ND = demand for intermediate goods/services by origin; $\mathrm{VA}=$ valueadded; $\mathrm{WTF}=$ trade in final goods; $\mathrm{XAp}=$ intermediate demand by destination; $\mathrm{XD}=$ demand for domestic goods; $\mathrm{XEp}=$ demand for energy by sector; $\mathrm{XMT}=$ demand for imports; $\mathrm{XP}=$ sector real output.

Source: Authors. 
Figure A1.4: Trade Aggregation

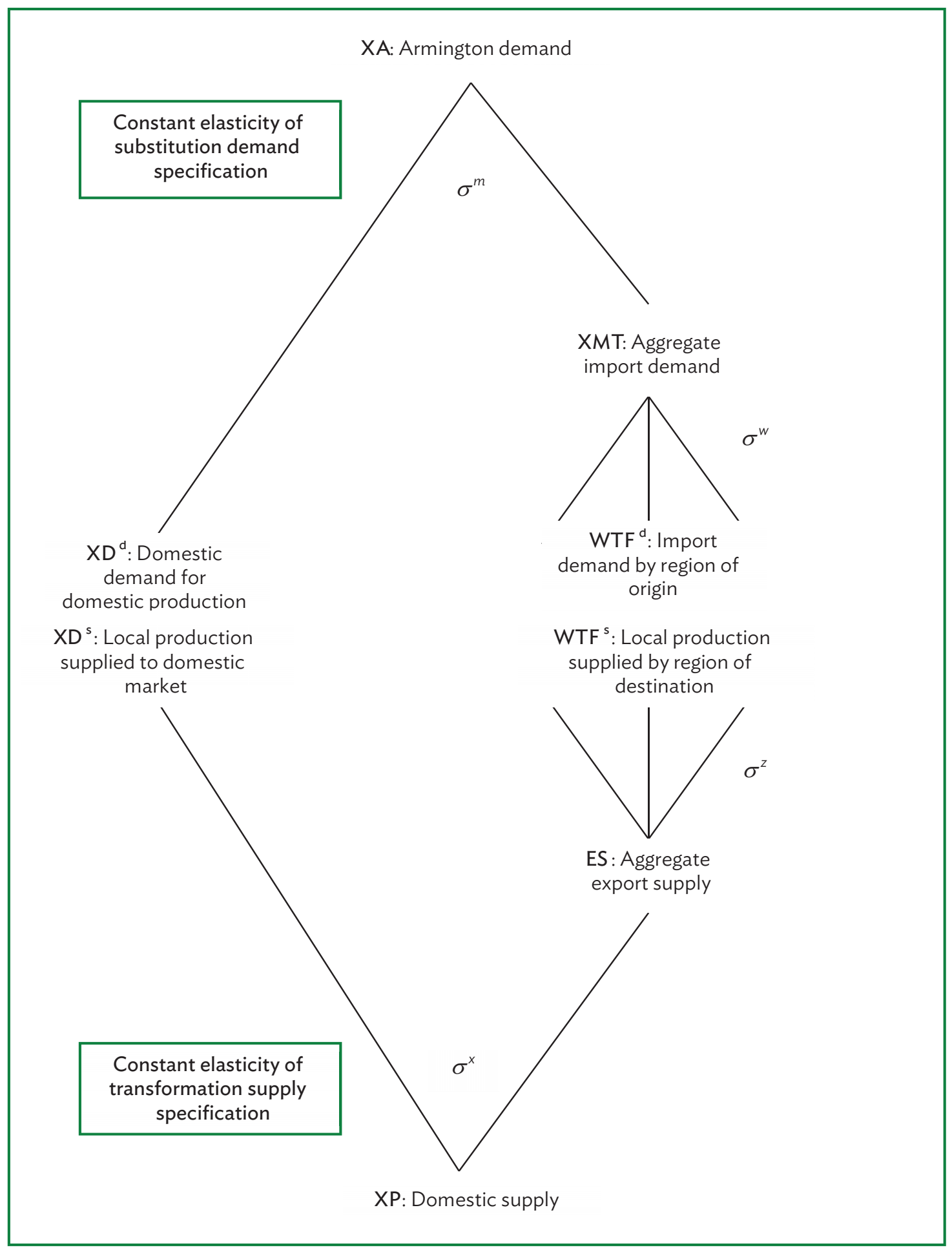

$E S=$ exports by commodity,$W T F=$ trade in final goods, $X A=$ aggregate demand by commodity,$X D=$ demand for domestic goods, $\mathrm{XMT}=$ demand for imports, $\mathrm{XP}=$ sector real output. Source: Authors. 


\section{APPENDIX 2: OVERVIEW OF MYANMAR DATA RESOURCES}

\section{A. Introduction}

In recent decades, data on socioeconomic performance of Myanmar have been fragmentary and subject to uncertain statistical standards. The urgent need for more reliable and timely data has attracted the attention of the current government, and it has announced its intention of resolving the issue by 2014. Strong political commitment to improve the standards of collecting, recording, and reporting is indicative of Myanmar's desire to participate in the global economic system. Therefore, recent official attempts to alleviate the statistical uncertainty manifests itself through international assistance (from the United Nations, Asian Development Bank, and other organizations), and the administration of economic censuses that subscribe to international standards by 2014.

Historically, Myanmar conducted few surveys and censuses. Any available data is commonly based on outdated standards and inconsistent measures. As a consequence, little reliable information exists today on economic and social conditions in the country. Myanmar's first domestic statistical agency, Central Statistics and Economic Department (CSED) was established in 1952 under "The Central Statistical Authority Act," Act No 34. Its main function was to consolidate, analyze, and ensure the coordination of operations of all official bodies in the whole field of statistical operations. Over several years, a view that the CSED needed to be more effective led to various structural changes, which brought it under the supervision of the Ministry of Planning and Finance in 1974. Since then, the CSED has been reorganized as the Central Statistical Agency (CSO) and is currently administered by the Ministry of National Planning and Economic Development (consequent on the Ministry of Planning and Finance being decentralized into two separate ministries).

Over the years, Myanmar's momentum to make nationwide statistical documentation a ubiquitous practice has been variable. Looking back to attain a better understanding of Myanmar's statistical undertakings, we observe that the Population and Housing Census of 1953 was one of the country's first national surveys. Its second survey, the Annual Survey of Manufacturers, was subsequently conducted by the CSED in 1955, 1963, 1971, and 1983-1984.

After the establishment of the State Peace and Development Council (SPDC), which implemented economic reform measures to redress the deteriorating economic situation of the country, several more national surveys were conducted as a sign of the country's meek attempt to increase the breath of its statistical domain. The CSO introduced the Packaging Survey (conducted in 45 townships in 1993), and the Private Sector Industrial Survey (PSIS, conducted nationwide in 2003 and 2006). The information from these national surveys enabled Myanmar to reap certain benefits as the 2003 PSIS survey accentuated the need for the development of an industrial sector based on natural resources. This led to the establishment of the Kalay industrial zone at the Hlaingtheyar township in 2004.

Among Myanmar's list of surveys, the Household Income and Expenditure Survey (HIES) is the CSO's main nationwide special-purpose survey, which has been carried out every 5 years since its introduction in 1989. Results from the HIES are used both as numeric weights for the calculation of Myanmar's Consumer Price Index (CPI) and for the calculation of its inflation rates. In addition, the ratio of the percent of total household expenditure spent between food and nonfood items serves as the CSO's main index for Myanmar's standard of living. So far, the HIES has been conducted in 1989, 1997, 2001, and 2006 (the gap between 1989 and 1997 is illustrative of the lack of political dedication behind regular data consolidation, which eventually received renewed emphasis in the mid-1990s). 
Whenever the HIES is conducted by other ministries, CSO officials act as members of a "steering" committee that supervise and engage in further analysis.

However, one of the main issues with Myanmar's statistical consolidation is its consistency and an apparent inability to administer nationwide censuses with regularity. Evidence of Myanmar's irregular reporting behavior is demonstrated in the absence of an official Population Census since 1983. This has caused approximations of Myanmar's current population to range from below 50 million to above 60 million. Given this statistical shortfall, Myanmar's current source of population data is the Vital Registration. Vital Registration statistics are compiled by the Department of Health, and processed by the CSO. In other words, national surveys on fertility and reproductive health conducted in 1991, 1997, 2001, and 2006 by the Department of Health (DOH) are used as loose indicators to estimate the country's demographic growth. These indicators are complemented with demographic surveys conducted by various government departments, such as the CSO, the Department of Population (DOP), in order to provide a combined appraisal of the country's demographic climate. Thus, the quality of the country's statistics commonly rests on unreliable and opaque procedures.

Expanding the scope of its statistical surveillance (by increasing the number of different surveys), without standardized procedural measures and appropriate continuity in data consolidation is indicative of the grave uncertainties that can arise in Myanmar's data. Nevertheless, over the last decade, there have been renewed efforts to broaden Myanmar's national statistical domain. Most notably is its greater attention to industry and market censuses. The Industry Survey (in 2003, 2006, 2008, which it now conducts annually), the Informal Sector Survey (in 2009), and the Whole Sale Price Survey (in 2008) are several of the new national surveys conducted by the CSO and the Planning Department. Currently, the CSO publishes the following surveys:

i. Statistical Year Book (Annually)

ii. Selected Monthly Economic Indicator (Monthly)

iii. Agriculture Statistics of Myanmar (Every 4 years)

iv. Livestock and Fishery Statistics of Myanmar (Every 4 years)

v. Forestry Statistics of Myanmar (Every 4 years)

vi. Statistical Profile of Children and Women (Every 3 years)

vii. Household Income and Expenditure Survey (Every 5 years)

viii. National Mortality Survey (Every 10 years, 1999, and 2009)

ix. The Rural Development Survey (Every 2 years)

x. Nationwide Manufacturing Survey (NMS) (conducted in 2003 and 2006)

xi. The Manufacturing Census for the Private Industrial Zones (conducted in 2006, 2008, and 2009)

xii. Price Survey for Whole Sale and Retail Price (conducted in 2008)

xiii. Informal Sector Survey (conducted in 2009)

These gradual increments of economic censuses serve as a partial solution to resolving the country's national statistical challenges. From the list above, it is evident that the time intervals between each report are relatively inconsistent. Therefore, it is also important that Myanmar improve on the regularity of reporting, reliability of statistical standards, and the accessibility of its official data. An assessment of the reliability of its official statistics in terms of coverage, accessibility, and regularity follows. 


\section{B. Agricultural Statistics}

Sound agricultural statistics and information will possess an increasing importance in developing Myanmar's agriculture sector. So far, Myanmar has conducted four agricultural censuses since its independence. The first agricultural census was conducted in 1952, while the second agricultural census was administered in 1993. Its third agricultural census was launched in 2003 and was executed according to guidelines set by the Food and Agriculture Organization's (FAO) World Census of Agriculture 2000 program. Although Myanmar's participation in the FAO's World Census of Agriculture 2003 and 2010 rounds have significantly improved its agricultural statistics, it is still far from the prevailing international standards. Statistical data officially published by the Ministry of Agriculture and Irrigation (MOAI) is still limited in its quantity and scope. Furthermore, Myanmar's current mechanisms and common procedures of statistical collection fail to assure a high degree of reliability, timeliness, and accuracy. Therefore, forecasting and data analysis that requires agricultural data remains a relatively challenging endeavor.

\section{National Accounts Statistics}

Although national accounts statistics are published annually, they are typically reported late and at irregular time intervals. Moreover, the accuracy of the reported national accounts does not provide a comprehensive economic overview due to the unavailability of standardized procedures in sampling its domestic private sector. Hence, the lack of proper mechanisms for data collection, coupled with the CSO's pressing resource constraints, impedes Myanmar's ability to conduct adequate data collection of an acceptable quality. These shortfalls impact its national accounts in several ways: i) Many services (such as restaurant dining, transportation, financial services) and processing goods are poorly estimated; ii) Taxes and subsidies on imported products are imprecisely recorded; iii) Domestic construction growth is based on the number of permits granted annually; and iv) GDP estimates do not completely account for informal sector activity (although there have been recent attempts to quantify the size of this growing sector).

\section{External Sector Statistics}

Myanmar has several issues in the reporting of its balance of payments (BOP). Most immediate of these is the exclusion of imported official goods, such as military equipment, merchandise imports, and import-related FDI under joint venture agreements. Income, goods, and services, are not only recorded using inconsistent consolidation procedures (which fail to adequately account for the majority of the population), but also fail to account for transactions that occur between local residents and foreigners. In addition, service and financial transactions that are not executed through official banking channels are not recorded, suggesting that a major gap may exist in financial statistics.

Besides the exclusion of the aforementioned variables from the BOP, several data entries are not properly measured. Proper classification of FDI, official reserves, external assets is lacking, and the evaluation of external debt not denominated in United States dollars is omitted. Therefore, the Index of Industrial Production (IIP) data (which depends on the proper assessment of BOP flows) is highly questionable. 


\section{E. Public Finance and Price Statistics}

Currently, Myanmar does not have monthly or quarterly fiscal data. Most of its fiscal data is reported on an annual basis, with typical delays of varying time intervals (although 12-month delays have been fairly common). Reporting standards for public financial statistics are irregular as state-owned enterprises either record transactions on a cash or on an accrual basis. Moreover, budgeted and actual expenditure estimates tend to vary significantly, resulting in unreliable debt statistics.

As for Myanmar's price statistics, its consumer price index (CPI) weights currently rely on the HIES conducted in 2006. These CPI weights only incorporate urban household expenditures, while it neglects rural household expenditures. Implied rents of owner-occupied housing also seem to be excluded from the calculation of CPI weights, and the classification of various items have to be updated to meet international standards. The CSO is aware of these discrepancies and is planning to rectify these issues, using weights based on HIES results conducted in 2012, before the publication of its new CPI in 2014.

\section{F. Industrial Statistics}

Since 1992, the Myanmar government has established private industrial zones in Yangon, Mandalay, Taungyi, Monywa, and some other towns. Thus far, there are 26 industrial zones in the country. In the past few years, industrial survey questionnaires have been collected by the Planning Department at an increasing frequency. However, the availability of reliable industrial data is still problematic, as industrial record systems and their associated registries are largely manually operated. Manpower shortages for all levels of the statistical organization, particularly for ground-level data collection, have also contributed to irregularities in industrial data collection. These basic operational issues cause Myanmar to fall short in its ability to report comprehensive statistical reports such as industry InputOutput (I-O) tables (1995 being the last year it reported an official I-O table).

However, the greatest statistical void present in Myanmar's industrial data consolidation is from its private sector. Given that many business enterprises scattered throughout the country are relatively small in their operational scale and have not been officially registered, more exhaustive measures need to be implemented to capture their collective economic contributions. Monthly and quarterly manufacturing surveys need to be instituted so as to comprehensively tabulate public and private value-added toward GDP, indices of production, and to track trends in wages and salaries. Furthermore, industrial data should be compiled in accordance with the International Standard Industrial Classification (ISIC) format, rather than merely an integration of 13 categories, which are currently applied.

\section{G. Monetary Statistics}

The Central Bank of Myanmar (CBM) currently conducts monetary surveys on both public and commercial banks. Most of these surveys are reported in accordance with the Monetary and Financial Statistics Manual (MFSM) established by the International Monetary Fund (IMF) through Standardized Report Forms. Although reporting standards are improving, greater investment to develop rigorous consolidation methods is still needed. Adopting market valuations of financial instruments, monitoring inter-bank accounts between commercial and public banks, using better technology to consolidate and share data (to minimize inconsistencies), and reviewing the accuracy of the CBM's balance sheet, will considerably increase the reliability of Myanmar's monetary statistics. 
Since Myanmar's move into the global economy in 2010, the CSO and various other departments have fully recognized the importance of proper statistical consolidation. Among several plans to improve the quality and accessibility of its economic data, the CSO and other government agencies have made a concerted effort to increase the number of economic surveys and to review the procedural methods of several surveys presently conducted; many of these surveys will be monitored by international agencies to meet international reporting standards. Several of its new national surveys are described below.

\section{Nationwide Manufacturing Survey (NMS)}

Presently, of the 7,000 enterprises within Myanmar's 26 industrial zones, 98\% are privately owned. Thus, conducting the NMS in the private sector is an important goal for the CSO. The goal of mending the gaping private sector statistical void (in order to generate a complete assessment of manufacturing growth) requires a complete enumeration to be carried out for all private industrial zones. However, much improvement on NMS data has to be made as many indicators have inconsistent procedural methods. While much technical and financial assistance is still required to rectify these complications, the concerned authorities are now attempting to apply the Myanmar Standard Industrial Classifications (MSIC) for its next NMS.

\section{Distributive Trade Statistics Survey (DTSS)}

Distributive trade is of great interest to the government for forecasting purposes, as changes in the value of trade and its volume (especially in cross border trade) is regarded as an important short-term indicator of economic activity. Therefore, the government plans to conduct several sample surveys of wholesale centers in large cities.

\section{a. Mass Media Survey (MMS)}

The prevalence of private sector mass media assets is observed to be increasing significantly from year to year. Growing mass media asset consumption includes items such as cellular phones, satellite televisions, computers, and media broadcasts. Information from this survey would bolster attempts to track the consumption patterns and help assess the degree of domestic technological penetration.

\section{b. Housing Construction Survey (HCS)}

The Ministry of Construction is planning to conduct an HCS to address the issue of housing shortages, especially in populous provinces, such as Yangon, where over a million residents still live in low-quality housing. Moreover, various rural-urban push-pull factors, resulting from Myanmar's recent global economic engagement, have caused an influx of rural migrants-inevitably impacting the availability of housing and its prices.

The most recent international initiative to improve data collection in Myanmar is collaboration between local authorities and the Asian Development Bank (ADB). ADB has administered a $\$ 1.2$ million Technical Assistance Grant from the Japan Fund for Poverty Reduction (JFPR). This grant aims to improve Myanmar's technical, legal, and institutional frameworks by upgrading its statistics law, updating data collection procedures, ensuring the implementation of international standards, establishing proper compilation and dissemination methods. 
In light of Myanmar's historical and contemporary statistical uncertainties, and the rising importance of accurate statistics as reform strategies are under development, there is strong interest in developing the necessary infrastructure and technical knowhow to provide statistical information that meets international standards. Currently, Myanmar's economic data stock is weakened by fragmented and unreliable information, reported at inconsistent time intervals. Moreover, alternate sources for the country's statistics from international and independent bodies are scant, largely due to historic limitations of reporting commitments. Despite all these constraints, promising signs of improvement are evident as the current government continues to pursue its mandate for global market and institutional engagement. 


\section{BIBLIOGRAPHY*}

Aghion, P. and P. W. Howitt. 1998. Endogenous Growth Theory. Cambridge, MA: MIT Press.

Arora, S. 1999. Health and Long-Term Economic Growth: A Multi-Country Study. Ph.D. Dissertation, The Ohio State University.

- - 2001. Health, human productivity, and long-term economic growth. The Journal of Economic History, 61, 699-749.

Asian Development Bank. 2012. Myanmar in Transition: Opportunities and Challenges. Manila.

Asterious, D. and G. M. Agiomirgianakis. 2001. Human Capital and Economic Growth: Time Series Evidence from Greece. Journal of Policy Modeling. 23 (5). pp. 481-89.

Awokuse, T. O. 2003. Is the Export-Led Growth Hypothesis Valid for Canada? Canadian Journal of Economics. 36 (1). pp. 126-36.

- - . 2006. Export-Led Growth and the Japanese Economy: Evidence from VAR and Directed Acyclic Graphs. Applied Economics. 38 (?). pp. 593-602.

Bairoch, P. 1988. Cities and Economic Development from Dawn of History to Present. Chicago: University of Chicago Press.

Balassa, B. 1978. Exports and Economic Growth: Further Evidence. Journal of Development Economics. 5 (?). pp. 181-89.

Balasubramanyam, V. N., M. Salisu, and D. Sapsford. 1998. Foreign Direct Investment and Growth in EP and IS Countries. Economic Journal. 106 (434). pp. 92-105.

Barker, D. J. P., ed. 1991. The Childhood Environment and Adult Disease. Ciba Foundation Symposium. London: John Wiley and Sons.

Barro, R. 1991. Economic Growth in a Cross Section of Countries. Quarterly Journal of Economics. 106 (2). pp. 407-43.

- - 2003. Determinants of Economic Growth in a Panel of Countries. Annals of Economics and Finance. 4 (2). pp. 231-74.

Barro, R. and J. Lee. 1994. Sources of Economic Growth. Carnegie-Rochester Conference Series on Public Policy. Cambridge, MA: MIT Press.

Barro, R. and X. Sala-i-Martin. 1992. Convergence. Journal of Political Economy. 100 (2). pp. 223-51.

- - 1995. Economic Growth. New York: McGraw-Hill.

\footnotetext{
*ADB recognizes "China” as the People’s Republic of China, "Korea” as the Republic of Korea, and "Burma” as Myanmar.
} 
Basta, S. S., M. S. Soekirman, D. Karyadi, and N. S. Scrimshaw. 1979. Iron Deficiency Anemia and the Productivity of Adult Males in Indonesia. American Journal of Clinical Nutrition. 32 (4). pp. 916-25.

Becker, G. S. 1975. Human Capital: A Theoretical and Empirical Analysis. New York: Colombia University Press and National Bureau of Economic Research.

- - 1995. A Treatise on the Family. Enlarged Edition. Cambridge, MA: Harvard University Press.

Bhargava, A. 1997. Nutritional Status and the Allocation of Time in Rwandese Households. Journal of Econometrics. 77 (1).pp. 277-95.

Bhargava, A., D. T. Jamison, L. J. Lau, and C. J. L. Murray. 2001. Modeling the Effects of Health on Economic Growth. Journal of Health Economics. 20 (3). pp. 423-40.

Bils, M. and P. Klenow. 2000. Does Schooling Cause Growth? American Economic Review. 90 (5). pp. 1160-83.

Bloom, D. and D. Canning. 2000. The Health and Wealth of Nations. Science. 287 (5456). pp. 1207209.

Bloom, D. and J. Sachs. 1998. Geography, Demography, and Economic Growth in Africa. Brookings Papers on Economic Activity. 29 (2). pp. 207-96.

Bloom, D. E., D. Canning, and J. Sevilla. 2004. The Effect of Health on Economic Growth: A Production Function Approach. World Development. 32 (1). pp. 1-13.

Bloom, D. E., D. Canning, L. Hu, Y. Liu, A. Mahal, and W. Yip. 2010. The Contribution of Population Health and Demographic Change to Economic Growth in China and India. Journal of Comparative Economics. 38 (1). pp. 17-33.

Borensztein, E., J. Gregorio, and J. Lee. 1998. How Does Foreign Direct Investment Affect Economic Growth? Journal of International Economics. 45 (1). pp. 115-35.

Brooke, A., D. Kendrick, and A. Meeraus. 1992. GAMS: A User's Guide, Release 2.25. Danvers, MA: Boyd and Fraser/The Scientific Press.

Central Statistical Organization (CSO). 2003. Statistical Yearbook. Yangon, Myanmar: Ministry of National Planning and Economic Development.

Chakraborty, S., and M. Das. 2005. Mortality, Human Capital and Persistent Inequality. Journal of Economic Growth. 10 (2). pp. 159-92.

Coe, D. and E. Helpman. 1995. International Research and Development Spill Overs. European Economic Review. 39 (5). pp. 859-87.

Coe, D., E. Helpman, and A. W. Hoffmaister. 1997. North-South Research and Development Spill Overs. Economic Journal. 107 (440) pp. 134-49. 
Coelli, T. J. and D. S. P. Rao. 2005. Total Factor Productivity Growth in Agriculture: A Malmquist Index Analysis of 93 Countries, 1980-2000. New York: John Wiley \& Sons.

Costa, D. L. and R. H. Steckel. 1997. Long-Term Trends in Health, Welfare and Growth in the United States. In R. H. Steckel and R. Floud, eds. Health and Welfare During Industrialization. Chicago: University of Chicago Press.

Dar, A. and S. Amirkhalkhali. 2003. On the Impact of Trade Openness on Growth: Further Evidence from OECD Countries. Applied Economics. 35 (16). pp. 1761-66.

Dasgupta, P. 1993. An Inquiry into Well-Being and Destitution. Oxford: Oxford University Press.

De Mello, L. R. 1999. Foreign Direct Investment-Led Growth: Evidence from Time Series and Panel Data. Oxford Economic Papers. 51 (1). pp. 133-51.

De Long, J. and L. Summers. 1991. Equipment Investment and Economic Growth. Quarterly Journal of Economics. 106 (2). pp. 445-502.

_-_. 1993. How Strongly Do Developing Countries Benefit from Equipment Investment? Journal of Monetary Economics. 32 (3). pp. 395-415.

Easterlin, R. A. 2000. The Worldwide Standard of Living Since 1800. Journal of Economic Perspectives. 14 (1). pp. 7-26.

Eaton, J. and S. Kortum. 1997. Trade in Ideas, Patenting and Productivity in the OECD. Journal of International Economics. 40 (3/4). pp. 251-78.

Egreteau, R. 2012. The Burmese Jade Trail: Transnational Networks, China and the Relative Impact of International Sanctions on Myanmar's Gems. In N. Cheesman, et al., eds. Myanmar's Transition: Openings, Obstacles and Opportunities. Singapore: Institute of Southeast Asian Studies.

Esfahani, S. H. 1991. Exports, Imports, and Economic Growth in Semi-industrial Countries. Journal of Development Economics. 35 (1). pp. 93-116.

Food and Agriculture Organization of the United Nations (FAO). Statistics Division. FAOSTAT database. http://faostat3.fao.org

Fujita, K. and I. Okamoto, eds. 2009. The Economic Transition in Myanmar after 1988: Market Economy versus State Control. Singapore: National University of Singapore Press.

Ghartey, E. E. 1993. Causal Relationship between Exports and Economic Growth. Applied Economics. 25 (9). pp. 1145-52.

Goletti, F. 1999. Agricultural Diversification and Rural Industrialization as a Strategy for Rural Income Growth and Poverty Reduction in Indochina and Myanmar. MSS Discussion Paper No. 30. Washington: International Food Policy Research Institute. 
Gornall, J., R. Betts, E. Burke, R. Clark, J. Camp, K. Willett, and A. Wiltshire. 2010. Implications of Climate Change for Agricultural Productivity in the Early Twenty-First Century. Phil. Trans. R. Soc. B September 27, 20103651554 2973-2989; doi:10.1098/rstb.2010.0158 1471-2970.

Grossman, G. and E. Helpman. 1991. Innovation and Growth in the Global Economy. Cambridge, MA: MIT Press.

- - 1994. Endogenous Innovation in the Theory of Growth. Journal of Economic Perspectives. 8 (1). pp. 23-44.

Grossman, M. 1972. The Demand for Health: A Theoretical and Empirical Investigation. New York, NY: Columbia University Press.

Haddad, L. J. and E. B. Howarth. 1991. The Impact of Nutritional Status on Agricultural Productivity: Wage Evidence from Philippines. Oxford Bulletin of Economics and Statistics. 53 (1). pp. 45-68.

Heckman, J. J. 2005. China's Human Capital Investment. China Economic Review. 16 (1). pp. 50-70.

International Labor Organization (ILO). Yearbook of Labour Statistics. Geneva.

Iscan, T. 1998. Trade Liberalization and Productivity: A Panel Study of the Mexican Manufacturing Industry. The Journal of Development Studies. 34 (5). pp. 123-48.

Iyar, S. and C. J. Dalgaard. 2005. Total Factor Productivity Revisited: A Dual Approach to Development Accounting. IMF Staff Papers. 52 (1). pp. 82-102.

Johnson, P. and S. Nicholas. 1997. Health and Welfare of Women in the United Kingdom, 1785-1920. In R. H. Steckel and R. Floud, eds. Health and Welfare During Industrialization. Chicago: University of Chicago Press.

Jones, C. I. 1995. Time Series Tests of Endogenous Growth Models. Quarterly Journal of Economics. 110 (2). pp. 495-525.

Kalemli-Ozcan, S., H. E. Ryder, and D. N. Weil. 2000. Mortality Decline, Human Capital Investment and Economic Growth. Journal of Development Economics. 62 (1). pp. 1-23.

Knowles, S. and D. Owen. 1995. Health Capital and Cross Country Variation in Income per Capita in the Mankiw-Romer-Weil Model. Economics Letters. 48 (1). pp. 99-106.

- - . 1997. Education and Health in an Effective Labour Empirical Growth Model. Economic Record. 73 (223). pp. 314-28.

Komlos, J. 1995. Biological Standard of Living on Three Continents: Further Essays in Anthropometric History. Boulder, Colorado: Westview Press.

Kremer, M. 1993. Population Growth and Technological Change: One Million B. C. to 1990. Quarterly Journal of Economics. 108 (3). pp. 681-716. 
Kubo, K. 2013. Real Exchange Rate Appreciation, Resource Boom and Policy Reform in Myanmar. Asian-Pacific Economic Literature. 27 (1). pp. 110-26.

Kudo, T. 1988. Industrial Policies and the Development of Myanmar's Industrial Sector in the transition to a Market Economy. In K. Fujita, et al., eds. The Economic Transition in Myanmar after 1988: Market Economy versus State Control. Singapore: National University of Singapore Press.

Lawrence, R. Z. and D. E. Weinstein. 1999. Trade and Growth: Import-Led or Export-Led? Evidence from Japan and Korea. NBER Working Paper No. 7264. Cambridge, MA: National Bureau of Economic Research.

Leibenstein, H. 1957. Economic Backwardness and Economic Growth: Studies in the Theory of Economic Development. New York: Wiley and Sons.

Li, X. and X. Liu. 2005. Foreign Direct Investment and Economic Growth: An Increasingly Endogenous Relationship. World Development. 33 (3). pp. 393-407.

Lichtenberg, F. R. 1992. R\&D Investment and International Productivity Differences. NBER Working Paper No. 4161. Cambridge, MA: National Bureau of Economic Research.

Lim, H. and Y. Yamada, eds. 2013. Economic Reforms in Myanmar: Pathways and Prospects. BRC Research Report No. 10. Bangkok, Thailand: Bangkok Research Center, Institute of Developing Economies-Japan External Trade Organization.

Lucas, R. E. 1988. On the Mechanics of Economic Growth. Journal of Monetary Economics. 22 (1). pp. $3-42$.

Maddison, A. 1995. Monitoring the World Economy 1820-1992. Paris: OECD Development Center Studies.

Mankiw, N. G., D. Romer, and D. N. Weil. 1992. A Contribution to the Empirics of Economic Growth. Quarterly Journal of Economics. 107 (2). pp.: 407-37.

Marin, D. 1992. Is the Export-Led Growth Hypothesis Valid for Industrialized Countries? Review of Economics and Statistics. 74 (4). pp. 678-88.

Marwah, K. and L. R. Klein. 1996. What are Some Prospects for India's Joining the Asian Growth Process? In R. Hooley, et al., eds. Asia Pacific Economic Cooperation: Theory and Practice. Research in Asian Economic Studies (Part B), Vol. 7. JAI Press.

Marwah, K. and A. Tavakoli. 2004. The Effect of Foreign Capital and Imports on Economic Growth: Further Evidence from Four Asian Countries. Canada: Carleton Economic Papers.

Mayer, D. 2001. The Long-Term Impact of Health on Economic Growth in Latin America. World Development. 29 (6). pp. 1025-33. 
Mazumdar, J. 2002. Imported Machinery and Growth in LDCs. Journal of Development Economics. 65 (1). pp. 209-24.

Mckeown, T. 1976. The Modern Rise of Population. London: Edward Arnold Publishers.

McKinsey Global Institute. 2013. Myanmar's Moment: Unique Opportunities, Major Challenges.

McNeill, W. H. 1998. Plagues and Peoples. New York: Anchor.

Mincer, J. 1974. Schooling, Experience and Earnings. New York: Columbia University Press.

Myint, C. C. 1996. Input-Output Analysis and its Application to Myanmar Economy (1989-90). Unpublished M. Econ thesis. Yangon Institute of Economics, Myanmar.

Myint, H. 1971. The Inward and Outward-Looking Countries of Southeast Asia. In H. Myint, ed. Economic Theory and the Underdeveloped Countries. Oxford: Oxford University Press.

Narayan, S., P. K. Narayan, S. Mishra. 2010. Investigating the Relationship between Health and Economic Growth: Empirical Evidence from a Panel of 5 Asian Countries. Journal of Asian Economics. 21 (4). pp. 404-11.

Nelson, R. and E. Phelps. 1966. Investment in Humans, Technological Diffusion, and Economic Growth. American Economic Review. 56 (2). pp. 67-75.

Obwona, M. 2001. Determinants of FDI and Their Impact on Economic Growth in Uganda. African Development Review. 13 (1). pp. 46-81.

Organisation for Economic Co-operation and Development (OECD). 2010. OECD Statistical Compendium. Paris.

Pedroni, P. 1999. Critical Values for Cointegration Tests in Heterogenous Panels with Multiple Regressors. Oxford Bulletin of Economics and Statistics. 61 (November Special Issue). pp. 653-69.

Podrecca, E. and G. Carmeci. 2001. Fixed Investment and Economic Growth: New Results on Causality. Applied Economics. 33 (2). pp. 177-82.

Rebelo, S. 1991. Long-Run Policy Analysis and Long-Run Growth. The Journal of Political Economy. 99 (3). pp. 500-21.

Reher, D. 1995. Wasted Investments: Some Economic Implications of Childhood Mortality Patterns. Population Studies. 49 (3). pp. 519-36.

Richards, D. G. 2001. Exports as a Determinant of Long-Run Growth in Paraguay, 1966-96. Journal of Development Studies. 38 (1). pp. 128-46.

Rivera, B. and L. Currais. 2004. Public Health Capital and Productivity in the Spanish Regions: A Dynamic Panel Data Model. World Development. 32 (5). pp. 871-85. 
Romer, P. M. 1986. Increasing Returns and Long-Run Growth. Journal of Political Economy. 94 (5). pp. 1002-37.

_-_. 1990. Endogenous Technological Change. Journal of Political Economy 98 (5). pp. S71-S102.

Rosen, S. 1976. A Theory of Lifetime Earnings. Journal of Political Economy. 84 (3). pp. 545-67.

Sachs, J. and A. Warner. 1995. Economic Reform and the Process of Global Integration. Brookings Paper on Economic Activity. 26 (1). pp. 1-118.

- - . 1997. Sources of Slow Growth in African Economies. Journal of African Economies. 6 (3). pp. 335-76.

Sandberg, L. G. and R. H. Steckel. 1997. Was Industrialization Hazardous to your Health? Not in Sweden! In R. Floud and R. H. Steckel, eds. Health and Welfare During Industrialization. Chicago: University of Chicago Press.

Schneider, P. H. 2005. International Trade, Economic Growth and Intellectual Property Rights: A Panel Data Study of Developed and Developing Countries. Journal of Development Economics. 78 (2005). pp. 529-47.

Schultz, T. P. 1997. Assessing the Productive Benefits of Nutrition and Health: An Integrated Human Capital Approach. Journal of Econometrics. 77 (1). pp. 141-58.

Schultz, T. P. and A. Tansel. 1996. Wage and Labor Supply Effects of Illness in Cote D'lvoire and Ghana: Instrumental Variable Estimates for Days Disabled. Journal of Development Economics. 53 (2). pp. 251-86.

Schultz, T. W. 1960. Capital Formation by Education. Journal of Political Economy. 68 (6). pp. 571-83.

_-_. 1961. Investment in Human Capital. American Economic Review. 51 (1). pp. 1-17.

- - . 1971. Investment in Human Capital: The Role of Education and of Research. New York: The Free Press.

Scrimshaw, N. S. and G. J. E. Gordon, eds. 1968. Malnutrition, Learning and Behavior. Cambridge, MA: MIT Press.

Self, S. and R. Grabowski. 2004. Does Education at All Levels Cause Growth? India, a Case Study. Economics of Education Review. 23 (1). pp. 47-55.

Sharma, S. C., N. M. Norris, and D. W. Chung. 1991. Exports and Economic Growth in Industrialized Countries. Applied Economics. 23 (4). pp. 697-707.

Sheehey, E. J. 1992. Exports and Growth: Additional Evidence. Journal of Development Studies. 28 (4). pp. 730-34. 
Spurr, G. B. 1983. Nutritional Status and Physical Work Capacity. Yearbook of Physical Anthropology. 26 (Supplement S1). pp. 1-35.

Steckel, R. H. 2003. Stature and the Standard of Living. Journal of Economic Literature. 33 (4). pp. 190340.

Steckel, R. H. and R. Floud. 1997. Health and Welfare during Industrialization. Chicago: University of Chicago Press.

Strauss, J. and D. Thomas. 1998. Health, Nutrition and Economic Development. Journal of Economic Literature. 36 (2). pp. 766-817.

Suhariyanto, K. and C. Thirtle. 2001. Asian Agricultural Productivity and Convergence. Journal of Agricultural Economics. 52 (3). pp. 96-110.

Thein, M. 2004. Economic Development of Myanmar. Singapore: Institute of Southeast Asian Studies.

Trajtenberg, M. 1990. Economic Analysis of Product Innovation. Cambridge: Cambridge University Press.

Turnell, S. 2009. Fiery Dragons: Banks, Moneylenders and Microfinance in Burma. Copenhagen: NIAS Press.

United Nations. 2013. World Population Prospects: The 2012 Revision. United Nations Department of Economic and Social Affairs, Population Division. DVD Edition.

Webber, D. J. 2002. Policies to Stimulate Growth: Should We Invest in Health or Education? Applied Economics. 34 (13). pp. 1633-43.

Westerlund, J. 2006. Testing for Panel Cointegration with Multiple Structural Breaks. Oxford Bulletin of Economics and Statistics. 68 (1). pp. 101-32.

Wheeler, D. 1980. Basic Needs Fulfilment and Economic Growth: A Simultaneously Model. Journal of Development Economics. 7 (4). pp. 435-51.

Wilbur, W. L. and M. Z. Haque. 1992. An Investigation of the Export Expansion Hypothesis. Journal of Development Studies. 28 (2). pp. 297-313.

World Bank. World Development Indicators. http://data.worldbank.org/data-catalog/worlddevelopment-indicators (accessed January 2015).

World Bank. 1993. World Development Report 1993: Investing in Health. New York: Oxford University Press.

Yamada, H. 1998. A Note on the Causality between Export and Productivity. Economics Letters. 61 (1). pp. 111-14.

Young, A. 1995. The Tyranny of Numbers: Confronting the Statistical Realities of the East Asian Growth Experience. Quarterly Journal of Economics. 110 (3). pp. 641-80. 
Yu, T. T. 1976. Input-Output Analysis and its Application to Myanmar Economy (1985-86). Unpublished M. Econ Thesis. Yangon Institute of Economics, Myanmar.

Zeigler, R. S. and D. W. Puckridge. 1995. Improving Sustainable Productivity in Rice-based Rainfed Lowland Systems of South and Southeast Asia. Geojournal. 35 (3). pp. 307-24. 


\section{Myanmar: Long-Term Scenarios for Sustained Macroeconomic Growth}

The paper uses a dynamic economic forecasting model to evaluate Myanmar's growth drivers to sustain its economic growth. Simulation results suggest that there is a broad horizon of opportunity for promoting rapid and inclusive economic growth. Increasing agricultural productivity, for example, will not only benefit the country's rural poor majority, but it will also release labor resources to facilitate industrial and service sector development. Conversely, industrial and urban development will facilitate agrifood supply chains, improving market access and real rural incomes. Public commitments to improving infrastructure, education, and public health will also be essential to realizing Myanmar's vast economic potential.

\section{About the Asian Development Bank}

ADB's vision is an Asia and Pacific region free of poverty. Its mission is to help its developing member countries reduce poverty and improve the quality of life of their people. Despite the region's many successes, it remains home to approximately two-thirds of the world's poor: 1.6 billion people who live on less than $\$ 2$ a day, with 733 million struggling on less than $\$ 1.25$ a day. ADB is committed to reducing poverty through inclusive economic growth, environmentally sustainable growth, and regional integration.

Based in Manila, ADB is owned by 67 members, including 48 from the region. Its main instruments for helping its developing member countries are policy dialogue, loans, equity investments, guarantees, grants, and technical assistance. 